\title{
Phytoplankton-Macrophyte Interaction in the Lagoon of Venice (Northern Adriatic Sea, Italy)
}

\author{
Fabrizio Bernardi Aubry *, Francesco Acri, Gian Marco Scarpa $₫$ and Federica Braga $₫$ \\ National Research Council-Institute of Marine Sciences (CNR_ISMAR), Arsenale Tesa 104, Castello 2737/F, \\ 30122 Venice, Italy; francesco.acri@ismar.cnr.it (F.A.); gianmarco.scarpa@ve.ismar.cnr.it (G.M.S.); \\ federica.braga@ve.ismar.cnr.it (F.B.) \\ * Correspondence: fabrizio.bernardi@ismar.cnr.it
}

Received: 7 August 2020; Accepted: 7 October 2020; Published: 10 October 2020

\begin{abstract}
The coexistence of phytoplankton and macrophytes in the Lagoon of Venice (Northern Adriatic Sea, Italy) was investigated using in situ data collected monthly as part of International Long Term Ecosystem Research (LTER), together with satellite imagery for the period 1998-2017. The concentrations of chlorophyll $a$ and hydrochemical parameters were measured in three areas of the lagoon, where the expansion of well-developed stands of submerged vegetation was observed by remote sensing. Our results suggest interaction between phytoplankton and macrophytes (macroalgae and seagrasses) in the last few years of the time series, evidenced by decreasing chlorophyll $a$ concentrations in the vicinity of the macrophyte stands. The integration of LTER and remotely sensed data made it possible to evaluate the interaction of macrophytes and phytoplankton at the ecosystem scale for the first time in the Lagoon of Venice.
\end{abstract}

Keywords: phytoplankton and macrophytes; water quality; multiannual variation; International Long Term Ecosystem Research (LTER); remote sensing; Lagoon of Venice

\section{Introduction}

Coastal lagoons are characterized by strong spatial heterogeneity, widely fluctuating hydrological variables and seasonal patterns [1-3]. In these ecosystems, the pronounced heterogeneity of the habitat and the shallow waters allow the development of a range of trophic conditions. This, in turn, gives rise to a very diverse community of primary producers on multiple functional levels, such as macroalgae, marine phanerogams, benthic microalgae and phytoplankton.

Macrophytes (macroalgae and seagrasses) respond univocally to environmental stressors in aquatic environments and thus represent sensitive indicators of water quality and the ecological status of transitional waters [4-6]. They play a key role in primary production, regulating the nutrient cycles and contributing to water oxygenation [7]. Water clarity tends to be enhanced by submerged vegetation, because it prevents sediment resuspension and erosive processes [8], and, by attenuating current and wave energy, it also traps suspended particles. On the other hand, the distribution of submerged vegetation is controlled by light availability $[9,10]$. In very turbid waters, light cannot penetrate to the bottom, leading to a decline in macrophyte growth and distribution, while phytoplankton become the only primary producers [6]. In transitional waters, light attenuation can be due to both natural and human-driven processes such as (i) the physical characteristics of the area (water depth, sea-floor properties, tidal currents, freshwater run-off and associated sediment delivery from the drainage basin and wind- and wave-driven sediment resuspension), (ii) human activities (increased nutrient and sediment loading from runoff and sewage disposal leading to eutrophication and algal blooms, ship and boat wakes, fishing and clam harvesting, dredging and coastal engineering works), and (iii) regional weather patterns (e.g., extreme storms and altered rainfall patterns) [10-12]. These factors play a crucial 
regulating role in the competition between macrophytes and phytoplankton for light and nutrients, and their interaction is difficult to unravel in practice, also considering the positive water clarity feedback of the development of aquatic submerged vegetation. At the regional scale, both changes in temperature and precipitation may influence aquatic ecosystems and are expected to have consequences for the competition between submerged macrophytes and phytoplankton, but, as different effects may counteract each other, the overall result is difficult to predict [13]. Macrophytes and phytoplankton, together with macrobenthic and fish fauna, represent Biological Quality Elements (BQEs) in the Water Framework Directive (WFD 2000/60/EC). The quali-quantitative assessment of BQEs and their alternation or coexistence is necessary for gauging the overall state of water bodies and the long-term changes affecting them [14-16], and it is also useful in the design of future studies in conjunction with various types of impact assessment.

In the last fifty years, several changes have been observed in the composition of primary producers in the Lagoon of Venice (LoV). Since 1960, the seagrass meadows (Zostera, Cymodocea), which originally covered the whole lagoon, have almost completely disappeared [17,18], while until 1990, much of the lagoon was extraordinarily covered in monospecific meadows of Ulva rigida C. Ag., with standing crops of up to 550,000 tons in wet weight, overall net primary production exceeding 1.5 million tonnes and gross primary production 5-6 times higher [19]. After 1990, Ulva receded [20] owing to a combination of climate conditions [21] and lower nutrient inputs [22]. The lowest values were observed in the late 1990s, with mean macroalgal biomasses of $0.27,0.18$ and $0.66 \mathrm{~kg} \mathrm{fwt} \mathrm{m}^{-2}$ in the northern, central and southern areas of the lagoon, respectively [23]. However, other studies have demonstrated that in recent years, seagrass beds have increased again, covering several areas of the lagoon close to the three inlets $[18,24]$. Facca and co-workers [23] reported average seagrass biomasses of 0.63 and $1.99 \mathrm{~kg}$ fw t m $\mathrm{m}^{-2}$, respectively, in the central and southern basin of the LoV. As for microalgae, the period from 1970 to the late 1990s saw frequent phytoplankton blooms, mainly in the central and northern basins [19,25-29]. In 1984, a massive Cryptomonas sp. bloom (chlorophyll $a>500 \mu \mathrm{g} \mathrm{L}^{-1}$ ) and a Peridinium foliaceum bloom (chlorophyll $a>150 \mu \mathrm{g} \mathrm{L}^{-1}$ ) were observed [30]. Since the start of the century, there has been a decrease in the number of blooms and, more generally, in phytoplankton biomass in lagoon waters [29]. The last 20 years (1998-2017) have seen a general improvement in the ecological condition of the LoV: water transparency has increased due to several factors including declining river discharge [31], a reduction in clam harvesting and the resurgence of macroalgae and seagrasses [32]. Furthermore, mean relative oxygen has increased considerably, while concentrations of ammonia and nitrates have decreased significantly [31]. Concentrations of chlorophyll $a$ have decreased significantly due to lower nitrogen inputs, as well as the competition for nutrients between phytoplankton and the macrophytes (macroalgae and seagrasses) that have recently recolonized the lagoon [31].

Satellite remote sensing can complement in situ sampling by providing useful information and tools to support the long-term analysis of ecological patterns and environmental changes in aquatic ecosystems. Specifically, remotely sensed data have been used extensively for mapping the extent and spatial distribution of submerged aquatic vegetation in lacustrine and coastal environments. Recent reviews of the various methods for assessing bottom cover types in tropical and temperate latitudes were published [33-35]. The suitability of multispectral sensors for large-scale habitat mapping in shallow waters and, specifically, the long data series from Landsat satellites, which provide the only means of investigating retrospective long-term changes in submerged vegetation cover since 1972, were assessed [36-38].

In this study, we analysed the evolution of the trophic state, phytoplankton biomass and macrophyte coverage on the basis of a 20-year time series of in situ and satellite data at three sampling stations in the Lagoon of Venice used for Long Term Ecosystem Research (LTER) activities [31]. The main aims of this study were (i) to investigate, by means of remote sensing images, patterns of macrophyte colonization and interannual spatial variations based on data recorded in late spring-summer; (ii) to analyse the relationship between macrophyte-colonized areas and phytoplankton biomass; 
(iii) to ascertain how lagoon trophic trends influence phytoplankton and macrophyte coexistence and interaction.

\section{Area of Studies}

The LoV (Northern Adriatic Sea, Mediterranean Sea; Figure 1) is the largest wetland $\left(550 \mathrm{~km}^{2}\right)$ in the Mediterranean Sea [39]. It is surrounded by densely inhabited and industrial areas and affected by a high touristic pressure, as well as intensive fishing and aquaculture. It has an average depth of $1 \mathrm{~m}$ and is morphologically characterized by the presence of large shallow areas (tidal and subtidal flats) and a network of deeper $(5-10 \mathrm{~m})$ channels. The LoV is connected to the sea through three inlets, Lido, Malamocco and Chioggia, which divide the lagoon itself into three morphological basins: north, central and south [22], delimited by the Malamocco-Marghera industrial channel in the South and by the Burano-Torcello salt-marshes in the North (Figure 1). The area considered in this study encompasses the central and northern basins. The central basin is subject to the highest environmental impact due to strong nutrient enrichment from the city of Venice and the major islands, treated urban waste water from the urban centre of Mestre, the west of Venice on the lagoon margin and its hinterland, and the discharge of wastewaters and cooling waters from the nearby industrial areas $[20,22]$. It is in this basin that the highest concentration of nutrients is observed: specifically, ammonium concentrations are double those found in the northern and southern basins, while nitrate levels are four to five times higher [22]. The northern basin is characterized by the presence of tributaries draining the waters from an intensively cultivated hinterland. Both north and central basins have higher turbidity values than the southern lagoon, especially near the industrial area of Porto Marghera and on the northern side of Venice close to the mouths of the Marzenego, Dese and Siloncello rivers, where turbidity is very high [22]. In this study, 245 sampling campaigns were conducted monthly from 1998 to 2017 at three stations (San Giuliano, Fusina and Palude della Rosa: St.1, St.3 and St.5, respectively).

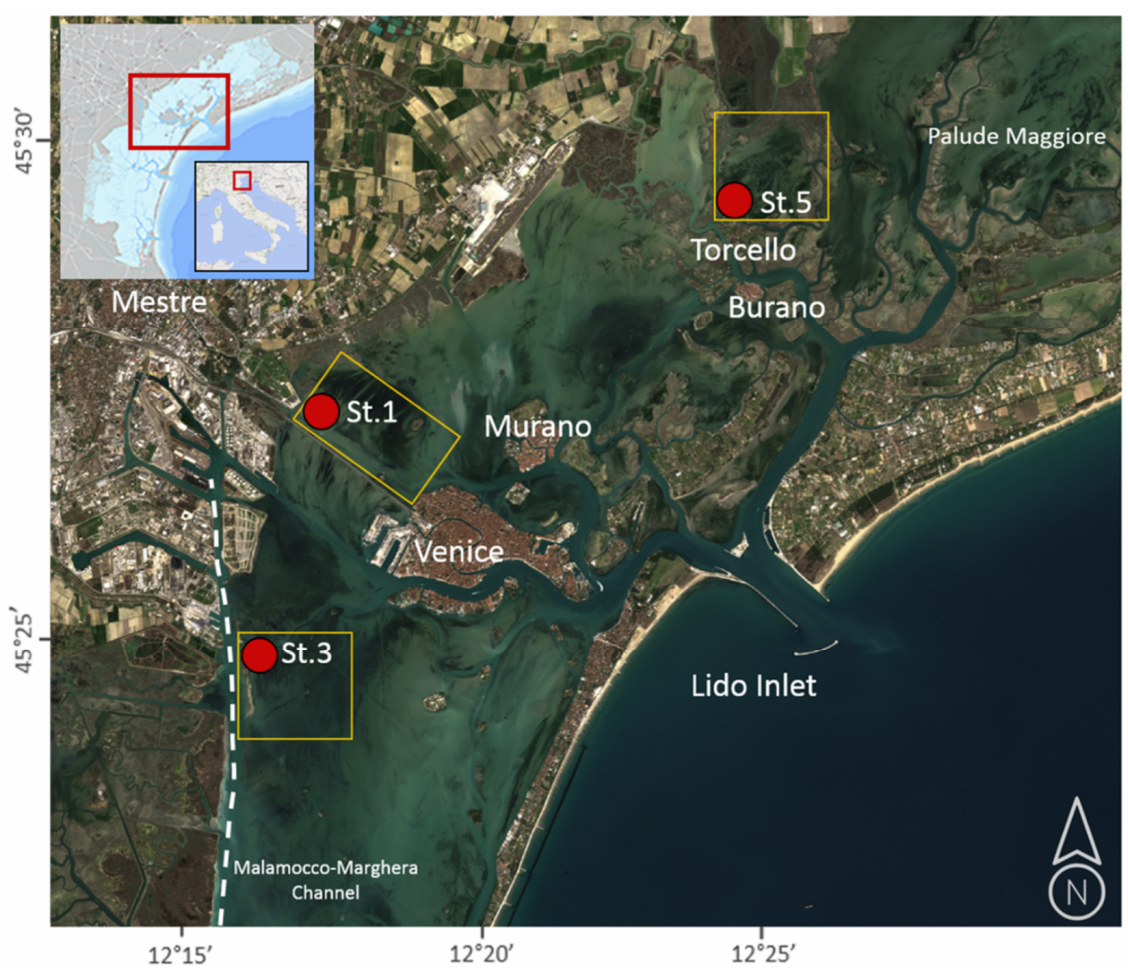

Figure 1. Copernicus Sentinel-2 (processed by European Space Agency) true-colour composite of the central area of the Venice Lagoon (19 March 2020) and the three sampling stations used for long-term data gathering. 
The stations, located in the central and northern basins, are influenced to varying degrees by marine and freshwater inputs: St.1, in the central basin, is located in an area of intense maritime traffic [40] that receives urban wastewaters from the town of Mestre, while St.3 is located in the central basin near the industrial area of Marghera in the vicinity of the thermoelectric power plant of Fusina and is also influenced by commercial ship traffic [27,41]. St.5 is located in the northern basin, a typical inland marshy lagoon area [40]. St.1 showed higher nutrient concentrations, greater phytoplankton biomass and abundance and lower salinity than St.3 and St.5. By contrast, the phytoplankton species compositions at the three stations did not vary significantly, the most abundant blooming species being largely shared by the three stations, whilst specific taxa associated with individual stations were rare [29]. In the first year of our time series, in the areas identified for sampling, the main primary producer was phytoplankton. Furthermore, in the central and northern basins, the macroalgal biomass appeared to be retreating, while seagrasses were the main primary producers in the southern basin and close to the seaward inlets [42,43].

\section{Materials and Methods}

\subsection{Hydrochemical Parameters}

Samples were collected monthly from January 1998 to December 2017 at a depth of $0.5 \mathrm{~m}$ at neap tide in order to minimize the effect of tidal hydrodynamics. The following parameters were measured: transparency, temperature, salinity, dissolved oxygen, chlorophyll $a$ and dissolved nutrients, including nitrogen as ammonium $\left(\mathrm{N}-\mathrm{NH}_{3}\right)$, nitrites $\left(\mathrm{N}-\mathrm{NO}_{2}\right)$ and nitrates $\left(\mathrm{N}-\mathrm{NO}_{3}\right)$ (summed and reported as dissolved inorganic nitrogen, $\mathrm{DIN})$ and phosphorus as orthophosphates $\left(\mathrm{P}^{-} \mathrm{PO}_{4}\right)$. Analytical quality was assessed via participation in the Quality Assurance of Information for Marine Environmental Monitoring in Europe (QUASIMEME [44]) international laboratory proficiency-testing programme. The laboratory analysis methods are described in detail in [31].

\subsection{Statistical Analyses}

An ANOVA (ANalysis Of VAriance) test followed by Tukey's test for post-hoc analysis was applied to compare the differences in the twenty-year hydrochemical datasets for the three sampling stations.

Interannual trends were analysed by applying the seasonal Mann-Kendall test, which takes account of the seasonality in the time series, to the whole dataset. This analysis determines the direction of trends (+ or -), goodness of fit (Kendall's tau) and statistical significance of the fit [45]. If a linear trend is present in a time series, then the true slope (change per unit time) can be estimated by using Sen's slope estimator [46,47]. To assess the evolution of macrophyte coverage, estimated every year in late spring-summer, which is representative of the maximum biomass extent [20,48,49], a simple Mann-Kendall test was used. Principal component analysis (PCA, R-mode) was used to identify relationships between environmental variables, displaying groups of observations (years) in a 2-dimensional space. For each year, the average macrophyte coverage, measured as a percentage in the three stations, and the respective yearly average values of the hydrochemical parameters were used. Thus, 19 values were obtained, one for each sampling year except for 2004, when the quality of the satellite image was not good enough to retrieve macrophyte coverage data. Any missing values were replaced by the means of the variables. The normality of the data for the PCA R-mode was verified using the Kolmogorov-Smirnov test. Differences between Cluster A and Cluster B means evidenced by principal component analysis were established using Student's $t$-test. ANOVA, Student's $t$-test, the Mann-Kendall test, PCA and the Kolmogorov-Smirnov test were performed using XLSTAT 2018.1. (Adinsoft, Paris, France). 


\subsection{Satellite Data and Processing}

The retrospective macrophyte coverage (seagrasses and macroalgae) was assessed using Landsat satellite imagery acquired in late spring-summer (i.e., in May and June), which is representative of the maximum biomass extent [20,48]. NASA's Landsat Earth global observation program started in the 1970s, providing a continuous record of the Earth's surface and making it possible to observe land use and land use change over time. The Thematic Mapper (TM), Enhanced Thematic Mapper Plus (ETM+) and Operational Land Imager (OLI) sensors, mounted on the Landsat satellites, have a spatial resolution of $30 \mathrm{~m}$, acquiring images every 16 days. They operate a suite of spectral bands covering the visible-to-near-infrared range, which is the region of interest for this study. Cloud-free and clear-water images from TM, ETM+ and OLI were used for mapping macrophyte coverage in the central and northern lagoon. Maps of species composition were not considered, because the Landsat spatial and radiometric resolution, and spectral band location and width are not suitable for distinguishing species types in very heterogeneous environments [50]. A common image-processing chain was used to obtain macrophyte distribution maps from the Landsat data, in accordance with [51-53]. In detail, the L1b level products, downloaded from USGS EarthExplorer (https://earthexplorer.usgs.gov), were converted into Top-of-Atmosphere radiances by applying radiometric calibration gains and atmospherically corrected using the vector version (6SV) of the Second Simulation of the Satellite Signal in the Solar Spectrum model [54]. The code was parameterized with reference to the Aerosol Optical Thickness at the time of image acquisition, obtained from AERONET (AErosol RObotic NETwork) [55], at the Acqua Alta Oceanographic platform, located 8 miles off Venice. The 6SV products were corrected for specular effects and converted to remote sensing reflectance $\left(R_{R S}\right)$ in accordance with [56]. The $R_{R S}$ products were then used as the input for a non-linear optimization algorithm called BOMBER (Bio-Optical Model Based tool for Estimating water quality and bottom properties from Remote sensing images) [57] in order to estimate substrate coverage in the lagoon. BOMBER was run in shallow water mode for the whole extent of the LoV, after the masking channel network. The algorithm was parameterized with reference to the extensive in situ dataset, which included spectral signatures of bottom cover, biogeophysical parameters, and apparent and inherent optical properties, collected in the last fifteen years in the LoV and along the coasts of the northern Adriatic Sea $[58,59]$. The outputs of BOMBER were the distribution maps of three different types of substrate: bare sediments, greenish macrophytes and darker macrophytes. The two macrophyte classes were added up and aggregated in order to obtain a macrophyte coverage map, in which each pixel of the maps quantified the proportion of the surface covered by submerged vegetation.

The BOMBER outputs were validated with thematic maps of seagrass distribution for the years 2009 [60] and 2017 [61], based on field surveys. A total of 47 randomly located control points were used to compare in situ and satellite-derived vegetation coverage, in a subset area colonized only by seagrasses. Satellite-derived product accuracy was quantified using a confusion matrix, built with three coverage classes.

The resulting submerged vegetation coverage maps for each year of the study period were imported into the QGIS (Quantum GIS Development Team, Version 3.6.0, Noosa) application as raster files. Each map was then converted into a vector file, in order to group the pixels into classes. Four categories of bottom coverage were selected in order to clusterize the data: 0 to $5 \%$ in the case of bare sediment, i.e., the absence of vegetation; 5 to $50 \%$ when the bottom was partially covered, i.e., with sparse vegetation; 50 to $75 \%$, indicating the widespread presence of vegetation in the form of moderately dense macrophyte meadows; and 75 to $100 \%$, corresponding to dense macrophyte meadows. The statistical data regarding bottom coverage for the three sampling sites were then extracted for each year of the study period using the statistical tool in QGIS for the spatial analysis. 


\section{Results}

\subsection{Hydrochemical Data: Comparison of Stations}

The stations are located in lagoon areas classified as polyhaline [62]. St.1 and St.5 were characterized by mean salinity values of 23.81 and 26.54, respectively, while St.3, affected by seawater from the ship channel connecting the Malamocco inlet with the industrial port of Marghera, had a value of 29.74 (Figure 1 and Table 1). The highest and lowest average transparency values were, respectively, observed at St.5 (Secchi Disk $=1.3 \mathrm{~m})$ and St.1 $(0.6 \mathrm{~m})$, the latter due to sediment resuspension in shallow water caused by ship wakes and tidal currents. At St.3, the average transparency was $1.0 \mathrm{~m}$. The presence of the power station near St. 3 caused it to have the highest mean water temperature $\left(22.8^{\circ} \mathrm{C}\right)$, while at St. 1 and St.5, the temperatures were, respectively, $17.0^{\circ} \mathrm{C}$ and $16.3^{\circ} \mathrm{C}$.

Table 1. Hydrochemical parameters in the three sampling stations: comparison of twenty-year averages ( $\mathrm{p}=$ probability level; $\mathrm{NS}=$ not significant).

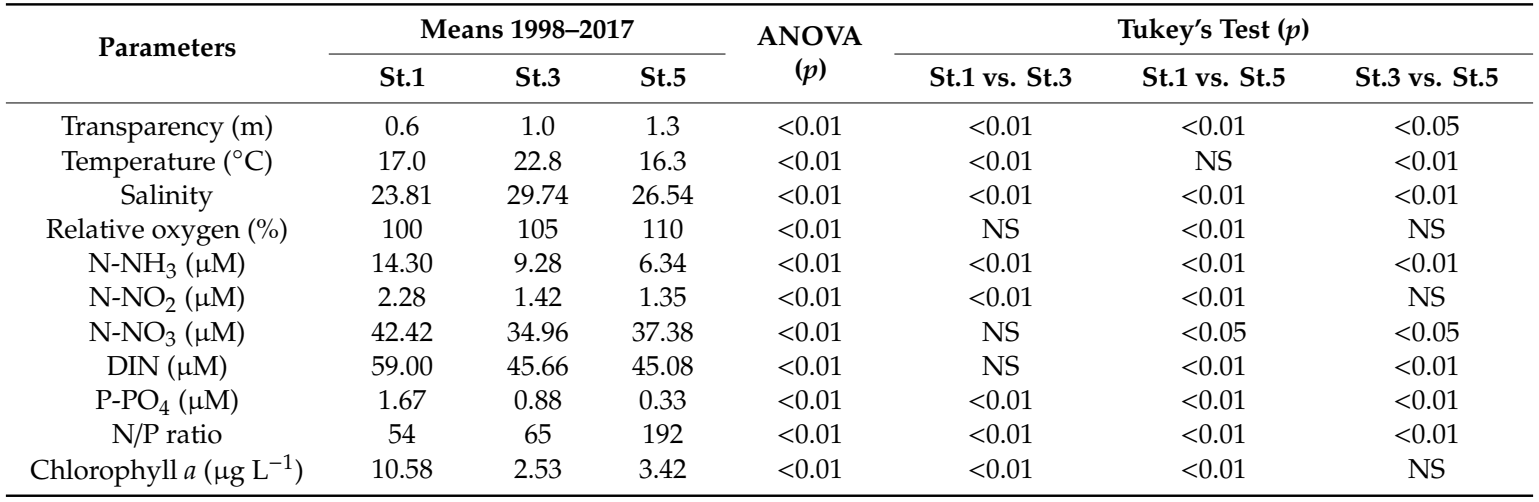

St.5 $\left(\mathrm{DIN}=45.08 \mu \mathrm{M}, \mathrm{P}^{-\mathrm{PO}_{4}}=0.33 \mu \mathrm{M}\right)$ has lower nutrient concentrations than St.1 $\left(\mathrm{DIN}=59.00 \mu \mathrm{M}, \mathrm{P}_{-} \mathrm{PO}_{4}=1.67 \mu \mathrm{M}\right)$ and St.3 (DIN $\left.=45.66 \mu \mathrm{M}, \mathrm{P}-\mathrm{PO}_{4}=0.88 \mu \mathrm{M}\right)$, as it is less affected by anthropogenic impacts. The low concentrations of phosphates at St.5 were responsible for the high N/P ratios (mean = 192) with respect to St.1 (54) and St.3 (65). At St.1, the highest nutrient concentrations supported greater phytoplankton biomass (chlorophyll $a=10.58 \mu \mathrm{g} \mathrm{L}^{-1}$ ) than that at St.3 (2.53 $\left.\mu \mathrm{g} \mathrm{L}^{-1}\right)$ and St.5 $\left(3.42 \mu \mathrm{g} \mathrm{L}^{-1}\right)$. Overall, the three stations differ significantly (Table 1). The only similarities are for temperature (St.1 and St.5), oxidized forms of nitrogen and chlorophyll $a$ (St.3 and St.5).

\subsection{Hydrochemical Data: Interannual Variability}

To obtain an overview of interannual variability, the data were averaged (yearly mean for each station), and the results are shown in Figures 2-4. Yearly averages of hydrochemical parameters in the three sampling stations for the whole study period are shown in Table S1_1, upplementary Materials. The lowest mean temperatures at St.1 and St.5 $\left(14.2^{\circ} \mathrm{C}\right.$ and $13.5^{\circ} \mathrm{C}$, respectively) were observed in 2002 and at St. $3\left(20.1^{\circ} \mathrm{C}\right)$ in 2010 , when one of the coldest years of the period 1998-2017 was recorded (Figure 5). The highest temperatures at St.1 $\left(19.1^{\circ} \mathrm{C}\right)$, St.5 $\left(18.2^{\circ} \mathrm{C}\right)$ and St. $\left(24.9^{\circ} \mathrm{C}\right)$ were, respectively, recorded in the years 2011, 2014 and 2015-2016, which were among the warmest years in the period 1998-2017 (Figure 5). Mean salinity was linked to precipitation, with the lowest values in rainy years and the highest in dry ones (Figure 6). 

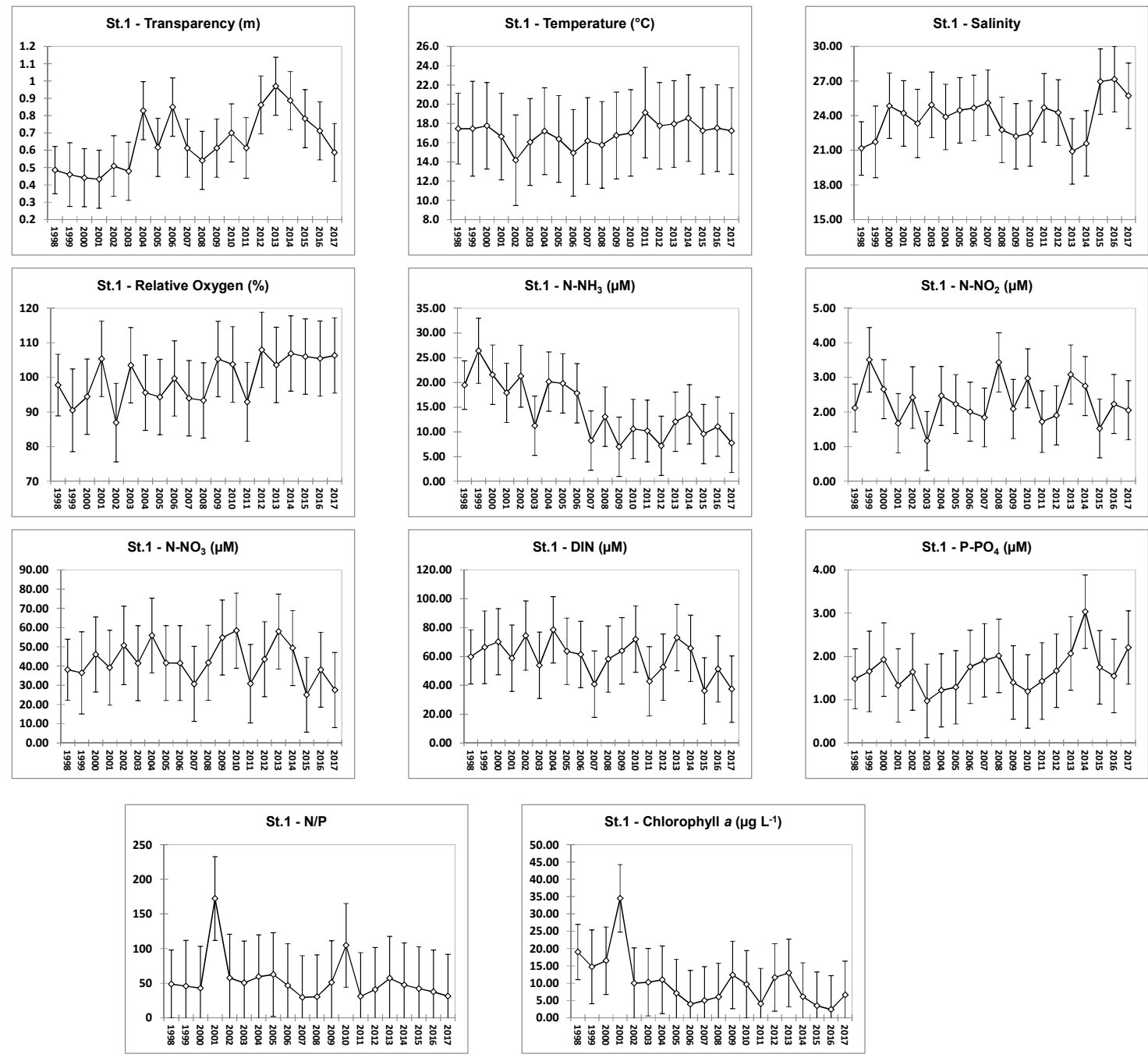

Figure 2. Yearly averages and confidence limits for hydrochemical parameters at St.1. Lower and upper bounds of means $(95 \%)$ are shown. 

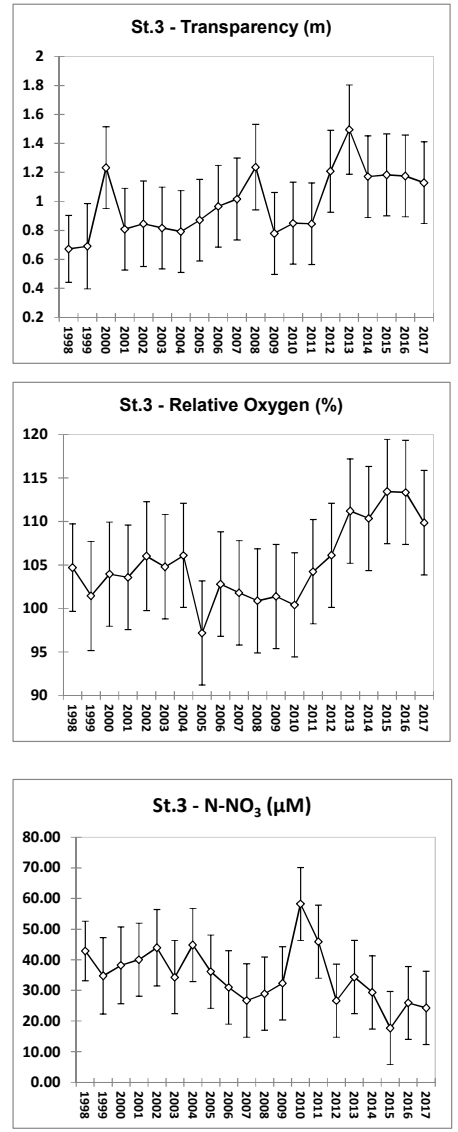
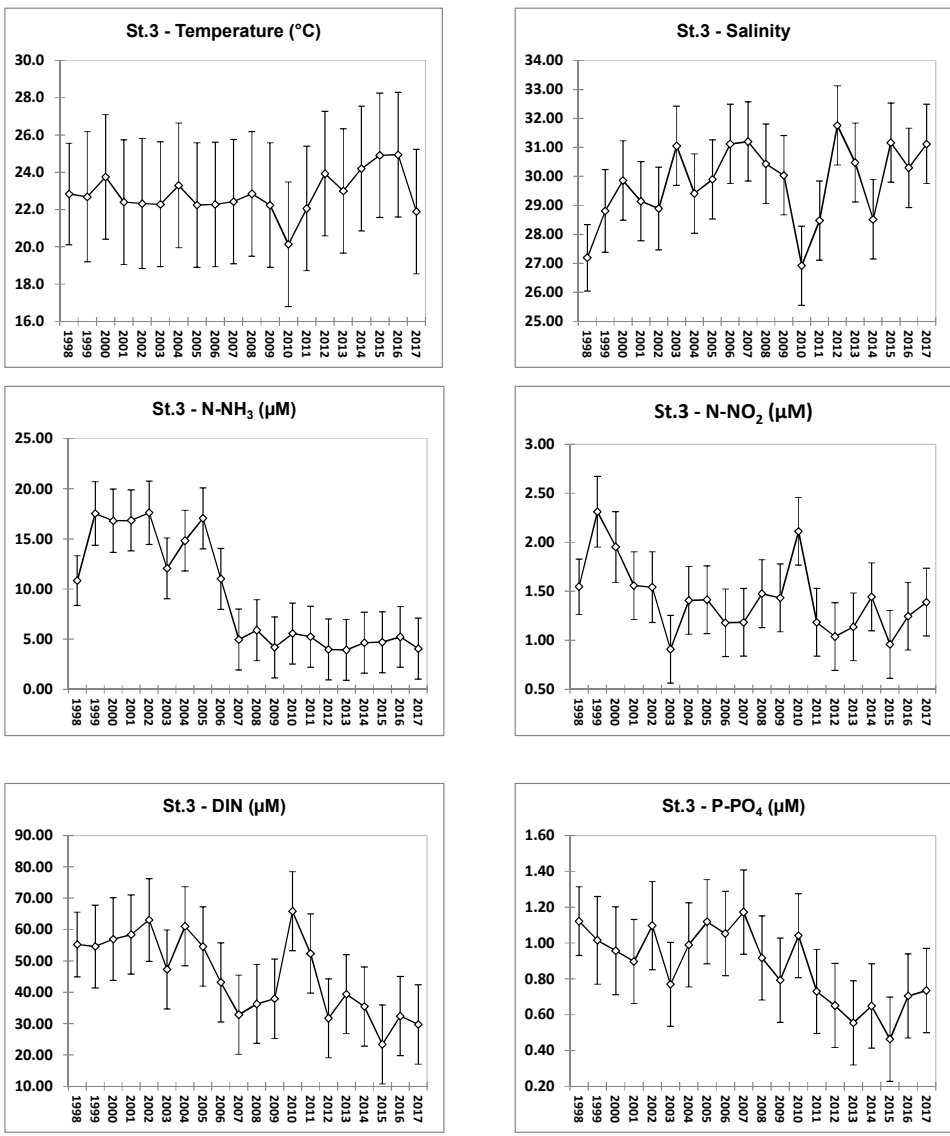
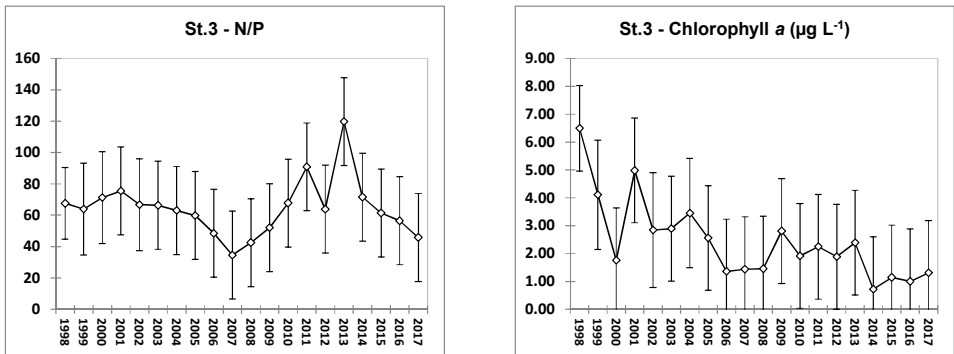

Figure 3. Yearly averages and confidence limits for hydrochemical parameters at St.3. Lower and upper bounds of means (95\%) are shown. 

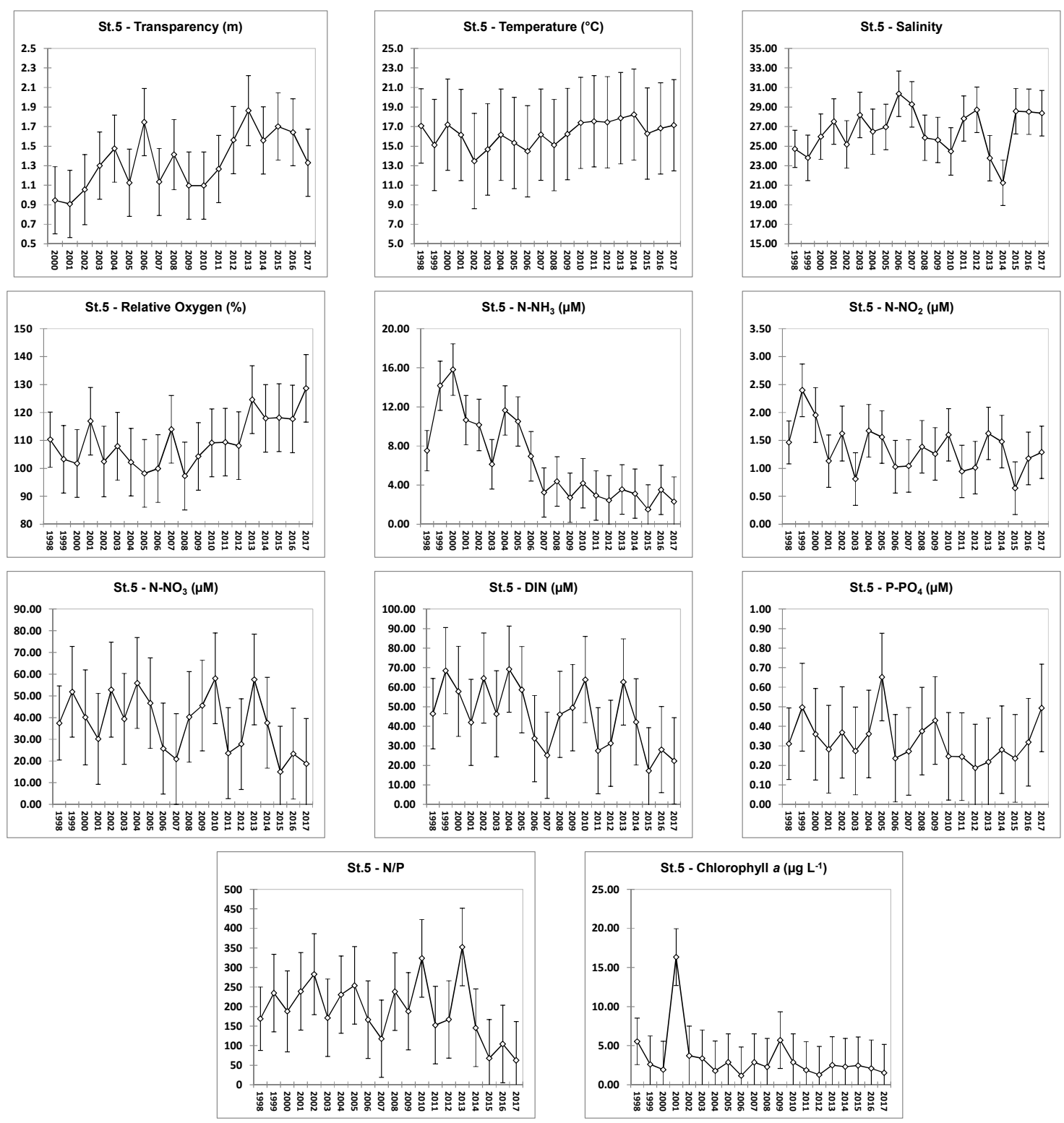

Figure 4. Yearly averages and confidence limits for hydrochemical parameters at St.5. Lower and upper bounds of means (95\%) are shown. 


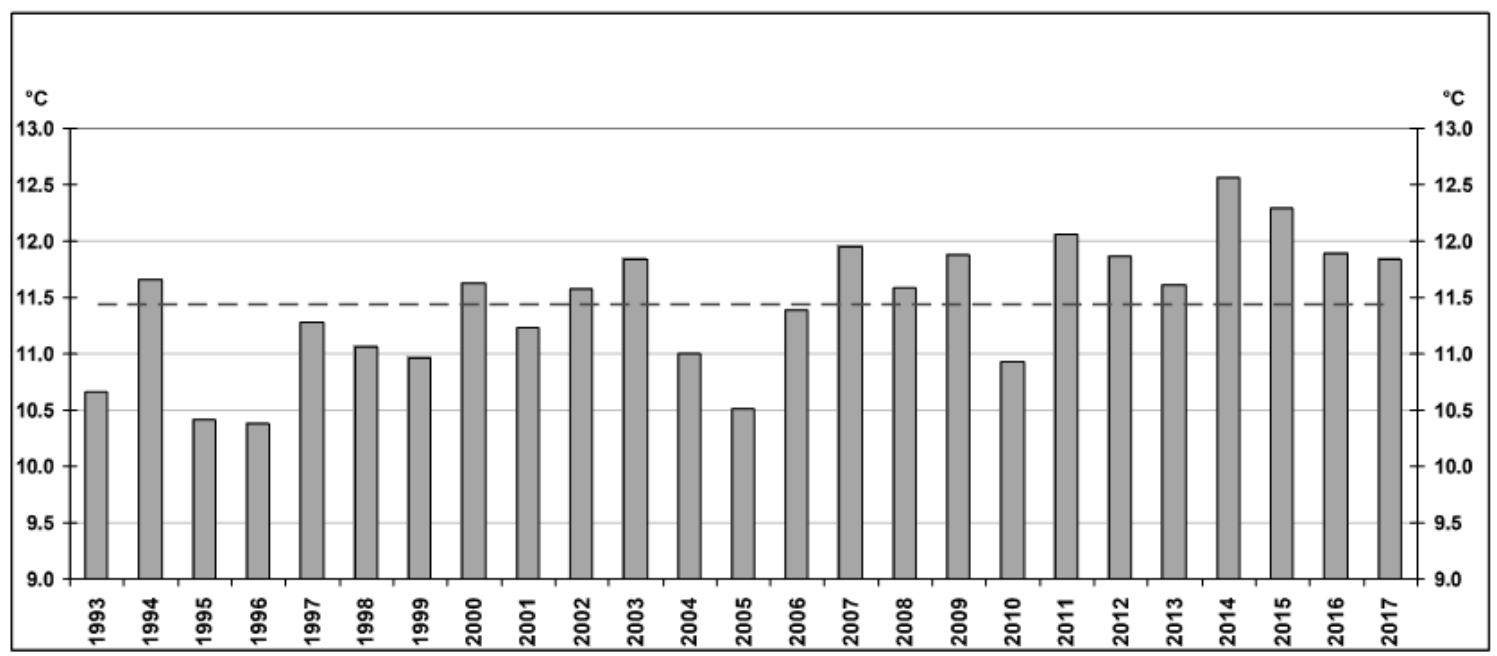

Figure 5. Mean air temperatures for the Veneto region. Weighted averages of 134 thermometric stations operating in Veneto in the period 1993-2017. The dashed line represents the mean for the period as a whole [63], modified.

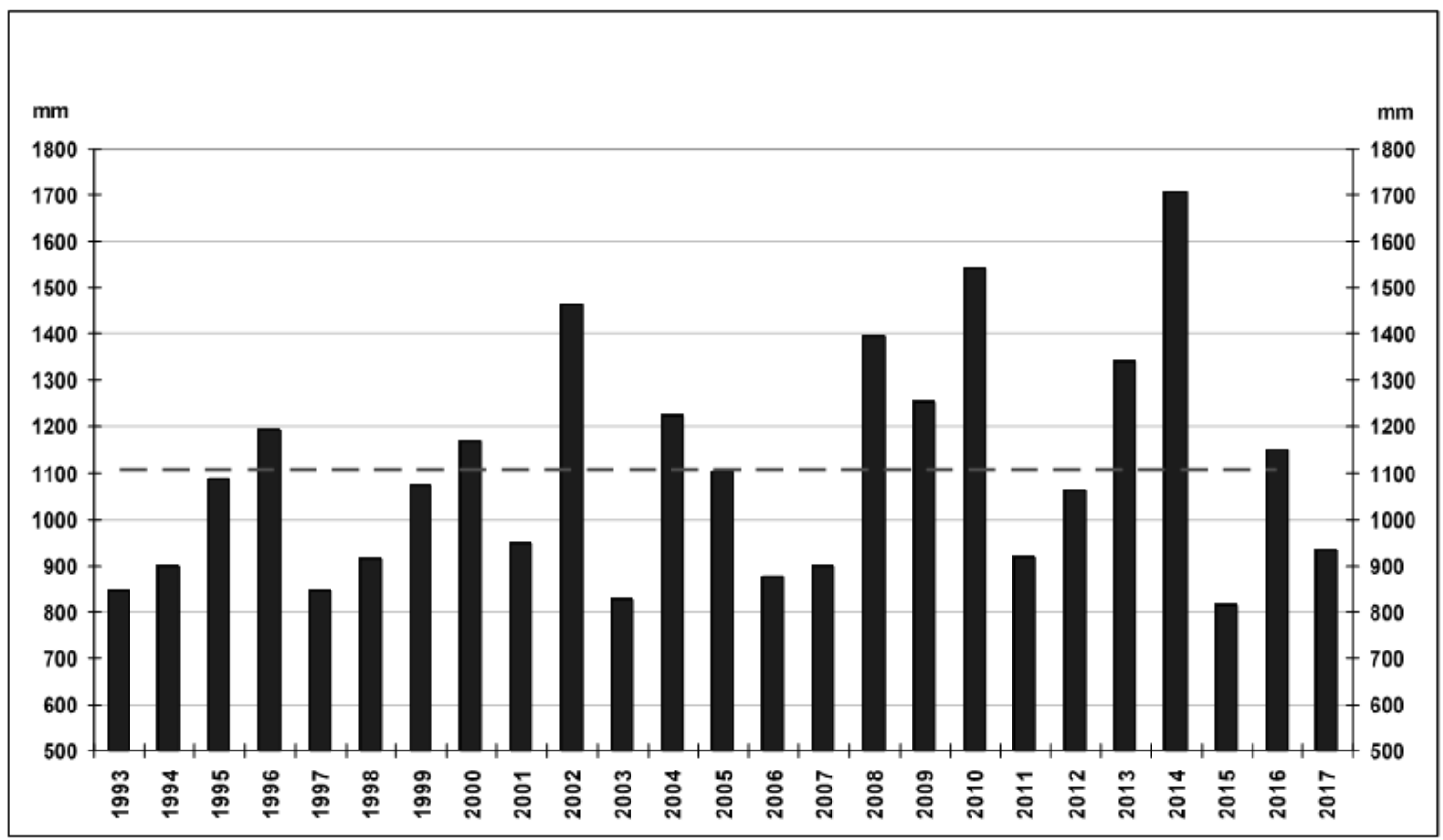

Figure 6. Mean annual rainfall from 1993 to 2017 for the Veneto Region. Weighted average of 160 rainfall stations in the period 1993-2017. The dashed line represents the average of the period as a whole [63], modified.

At St.1, the mean salinity varied between 20.91 in 2013 and 27.16 in 2016; at St.3, between 26.92 in 2010 and 31.76 in 2012; and at St.5, between 21.24 in 2014 and 30.36 in 2006. Both minimum and maximum transparency values were reached in 2000-2001 and 2013 at St.1 and St.5 (0.4-1.0 m and 0.9-1.9 m, respectively). At St.3, the highest mean transparency (1.5 m) was recorded in 2013 and the lowest $(0.7 \mathrm{~m})$ in 1998-1999. The mean relative oxygenation was the lowest at St.1 (87\% in 2002) and highest at St.5 (129\% in 2017); the mean values were generally higher in recent years (2012-2013). Concerning nutrients, from 2007 onwards, ammonia levels fell sharply at all the stations. The highest mean concentration was recorded at St.1 $(26.40 \mu \mathrm{M})$ in 1999, and the lowest, at St.5 $(1.50 \mu \mathrm{M})$ in 2015. Oxidized forms of nitrogen $\left(\mathrm{N}-\mathrm{NO}_{2}\right.$ and $\left.\mathrm{N}-\mathrm{NO}_{3}\right)$ did not see abrupt decreases after 2007. The highest 
mean nitrite levels were recorded in 1999 (3.51 $\mu \mathrm{M}$ at St.1, $2.31 \mu \mathrm{M}$ at St.3 and $2.40 \mu \mathrm{M}$ at St.5), and the lowest, in 2003 (1.17 and $0.91 \mu \mathrm{M}$ at St.1 and St.3, respectively) and 2015 (0.64 $\mu \mathrm{M}$ at St.5). At all stations, the highest mean nitrate concentrations were recorded in 2010: 58.45, 58.19 and 58.11 $\mu \mathrm{M}$ at St.1, St.3 and St.5, respectively. The lowest mean nitrate levels were measured in $2015(25.09,17.92$ and $15.09 \mu \mathrm{M}$ at St.1, St.3 and St.5, respectively), together with the lowest dissolved inorganic nitrogen (DIN) (36.19, 23.38 and $17.23 \mu \mathrm{M}$ at St.1, St.3 and St.5, respectively). The highest DIN levels were measured in 2004 at St.1 $(78.48 \mu \mathrm{M})$ and St.5 $(69.21 \mu \mathrm{M})$, and in 2010 at St.3 $(65.86 \mu \mathrm{M})$. At all stations, the trend in the DIN concentrations was similar to that for nitrates due to the prevalence of this form of nitrogen over the other two forms. The mean orthophosphate concentrations ranged between 0.97 and $3.03 \mu \mathrm{M}$ at St.1 in 2003 and 2014, respectively; between 0.46 and $1.17 \mu \mathrm{M}$ at St.3 in 2015 and 2007, respectively; and between 0.19 and $0.65 \mu \mathrm{M}$ at St.5 in 2012 and 2005, respectively. After 2011 at St.3, the concentrations were lower than in previous years, whilst no well-defined trends could be highlighted in the other two stations. At St.1, the N/P ratio saw an irregular trend with two peaks, the first in 2001 (172) and the second in 2010 (105). At St.3, the trend was also irregular, with a peak in 2013 (120). At St.5, the N/P ratio peaked in 2010 (323) and in 2013 (353), followed by a series of lower values in the last three years of sampling (2015, 2016 and 2017). High chlorophyll $a$ concentrations were measured in the years 1998-2001 at St.1, with a peak of $34.52 \mu \mathrm{g} \mathrm{L}^{-1}$ in 2001. The highest mean biomass was found at St.5 in the same year: $16.33 \mu \mathrm{g} \mathrm{L}^{-1}$. In the other years, however, apart from 1998 and 2009, the value barely exceeded $5 \mu \mathrm{g} \mathrm{L}{ }^{-1}$. At St.3, the highest mean concentration was $6.49 \mu \mathrm{g} \mathrm{L}^{-1}$ in 1998 , while the lowest was $0.72 \mu \mathrm{g} \mathrm{L}-1$ in 2014.

\subsection{Macrophyte Coverage}

The list of selected Landsat images used for the analysis and the derived maps of macrophyte coverage retrieved by BOMBER are shown in Table S2_1 and Figure_S2_1 Supplementary Materials, respectively. Thematic maps of submerged vegetation coverage were used to assess the accuracy of the outputs of the BOMBER bio-optical modelling and its ability to discriminate between bottom cover classes. Three different classes were selected to build a confusion matrix: bare sediment $=$ BS $(0-5 \%)$, Sparse Macrophyte $=$ SM (5-50\%) and Dense Macrophyte $=$ DM (50-100\%). The results of the confusion matrix showed that all the classes were recognized with an overall accuracy of $80.4 \%$ (Table 2). The two classes of BS and DM were mapped with high accuracy (81.5\% and $97.5 \%$, respectively). A slight misidentification was found for SM (56.7\%), because the relatively large pixel size of the Landsat data was unable to delineate small patterns of vegetation patches. Our results are consistent with findings obtained by [50].

Table 2. Confusion matrix for macrophyte coverage classes mapped from Landsat validated against reference cover estimated from thematic maps. BS = bare sediment, $\mathrm{SM}=$ Sparse Macrophyte, and DM= Dense Macrophyte.

\begin{tabular}{cccccc}
\hline \multicolumn{7}{c}{ In Situ } & & \\
\hline \multirow{4}{*}{ Classified } & BS & SM & DM & Producer's accuracy \\
& BS & 8 & 3 & 0 & $81.5 \%$ \\
& SM & 3 & 10 & 2 & $56.7 \%$ \\
& DM & 0 & 1 & 20 & $97.5 \%$ \\
& User's accuracy & $71.0 \%$ & $77.3 \%$ & $88.6 \%$ & $80.4 \%$ \\
\hline
\end{tabular}

Representative subsets of maps of the submerged vegetation around each sampling station were selected with reference to hydrodynamic and morphological criteria. For St.5, located at the entrance of a semi-enclosed basin, we took the whole confined basin into account. For St.1 and St.3, the subsets were selected considering the water circulation, the renewal capacity and the role of the main channels in confining the various sub-basins [64]. A graphical representation of the submerged vegetation coverage maps obtained for 2016 is presented in Figure 7. 
St.1

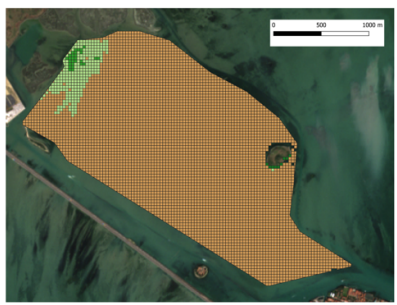

$\square 0-5$
St 3

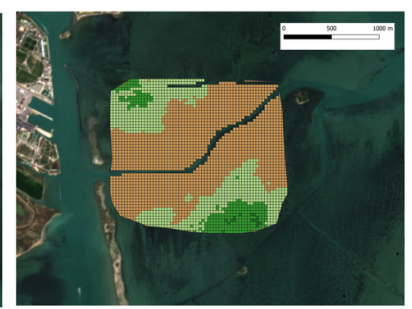

Coverage \%

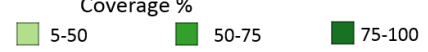

St.5

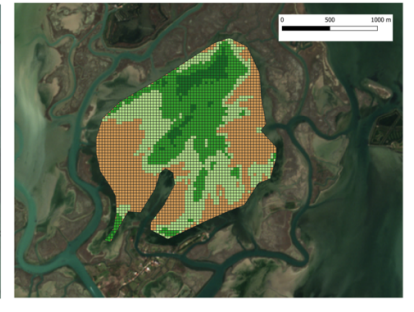

Figure 7. Macrophyte distribution derived from BOMBER and clustered in four categories of bottom coverage: 0 to $5 \%$ in the case of bare sediment; 5 to $50 \%$, sparse vegetation; 50 to $75 \%$, moderately dense macrophytes; and 75 to $100 \%$, corresponding to dense macrophyte meadows.

In the period 1998-2017, St.5 showed the highest mean macrophyte coverage (Figure 8): we assessed that, on average, $21 \%$ of the area was covered by macrophyte meadows with a density of $50-100 \%$. This was followed by St.3 (14\%) and St.1 (7\%). The maximum coverage (cover class > 75\%) was seen in 2015 at St.5 (65\%) and St.1 (39\%), and in 2013 at St.3 (60\%). From 1998, at the beginning of this study, until 2003, all three areas were almost uncolonized, while in the years 2005 and 2006 and 2010-2011, they were characterized by sparse or moderate communities (coverage between 5 and 50\%). In the years 2007 and 2008, all three sampling sites were characterized by an increase of 1-31\% in macrophyte coverage with a density of 50-100\%, while the last 5 years of our dataset (2013-2017) showed increases of $1-94 \%$ in macrophyte coverage, with a density of $50-100 \%$.

St.1
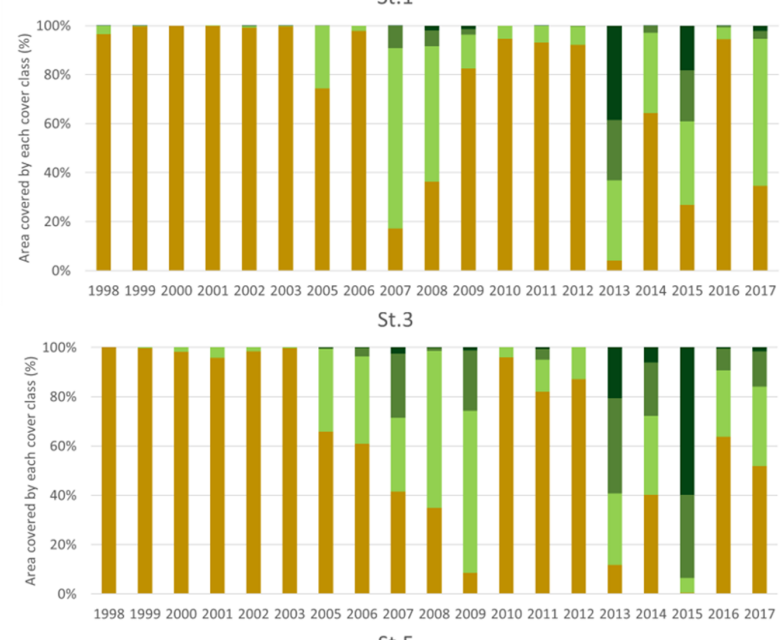

St 5

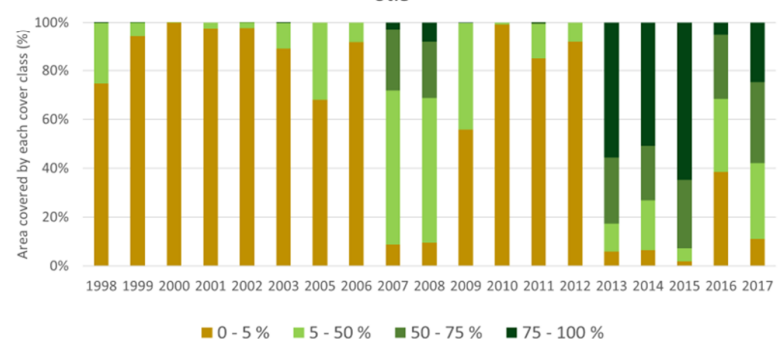

Figure 8. Trends (expressed in \%) in the four classes of bottom coverage for the 3 stations during the period 1998-2017: 0 to 5\% corresponds to bare sediment; 5 to $50 \%$, sparse vegetation; 50 to $75 \%$ moderately dense macrophyte meadows; and 75 to $100 \%$, dense macrophyte meadows. 


\subsection{Statistical Analysis of Trends}

At all three sampling sites, the transparency increased significantly. The temperature increased significantly at St.5, and salinity, at St.3 (Table 3). In each of the three sampling stations, there was a significant increase in relative oxygenation and a significant fall in ammonia concentrations. As for the oxidized forms of nitrogen, nitrite did not show any trend at St.1, while at St.3 and St.5, it decreased significantly; nitrates and DIN showed the same trends at St.3 and St.5.

Table 3. Seasonal Kendall tests of the hydrochemical parameters: Kendall's tau, significance of trend (p), and Sen's slope estimator in units $\mathrm{y}^{-1}$. Period: 1998-2017 (except for transparency in St.5, measured from 2000 onwards).

\begin{tabular}{|c|c|c|c|c|c|c|c|c|c|}
\hline \multirow[b]{2}{*}{ Parameters } & \multicolumn{3}{|c|}{ St.1 } & \multicolumn{3}{|c|}{ St.3 } & \multicolumn{3}{|c|}{ St.5 } \\
\hline & $\begin{array}{l}\text { Kendall's } \\
\text { Tau }\end{array}$ & $p$ & $\begin{array}{l}\text { Sen's } \\
\text { Slope }\end{array}$ & $\begin{array}{l}\text { Kendall's } \\
\text { Tau }\end{array}$ & $p$ & $\begin{array}{l}\text { Sen's } \\
\text { Slope }\end{array}$ & $\begin{array}{l}\text { Kendall's } \\
\text { Tau }\end{array}$ & $p$ & $\begin{array}{l}\text { Sen's } \\
\text { Slope }\end{array}$ \\
\hline Transparency (m) & 0.29 & $<0.01$ & 0.02 & 0.33 & $<0.01$ & 0.03 & 0.28 & $<0.01$ & 0.04 \\
\hline Temperature $\left({ }^{\circ} \mathrm{C}\right)$ & 0.06 & 0.19 & 0.18 & 0.11 & 0.06 & 0.12 & 0.14 & $<0.05$ & 0.16 \\
\hline Salinity & 0.09 & 0.11 & 0.06 & 0.16 & $<0.05$ & 0.08 & 0.06 & 0.40 & 0.00 \\
\hline Relative oxygen (\%) & 0.16 & $<0.01$ & 0.68 & 0.16 & $<0.05$ & 0.40 & 0.18 & $<0.01$ & 0.77 \\
\hline $\mathrm{N}-\mathrm{NH}_{3}(\mu \mathrm{M})$ & -0.25 & $<0.01$ & -0.53 & -0.49 & $<0.01$ & -0.64 & -0.46 & $<0.01$ & -0.44 \\
\hline $\mathrm{N}-\mathrm{NO}_{2}(\mu \mathrm{M})$ & 0.02 & 0.67 & 0.00 & -0.21 & $<0.05$ & -0.02 & -0.17 & $<0.01$ & -0.03 \\
\hline $\mathrm{N}-\mathrm{NO}_{3}(\mu \mathrm{M})$ & -0.02 & 0.73 & -0.10 & -0.26 & $<0.01$ & -0.80 & -0.19 & $<0.01$ & -0.55 \\
\hline DIN $(\mu \mathrm{M})$ & -0.07 & 0.12 & -0.50 & -0.39 & $<0.01$ & -1.48 & -0.27 & $<0.01$ & -1.28 \\
\hline $\mathrm{P}-\mathrm{PO}_{4}(\mu \mathrm{M})$ & 0.04 & 0.49 & 0.01 & -0.30 & $<0.01$ & -0.02 & -0.01 & 0.91 & 0.00 \\
\hline $\mathrm{N} / \mathrm{P}$ ratio & -0.14 & $<0.05$ & -0.66 & -0.08 & 0.23 & -0.49 & -0.19 & $<0.01$ & -4.38 \\
\hline Chlorophyll $a\left(\mu \mathrm{g} \mathrm{L}^{-1}\right)$ & -0.29 & $<0.01$ & -0.25 & -0.36 & $<0.01$ & -0.08 & -0.19 & $<0.01$ & -0.03 \\
\hline
\end{tabular}

Inorganic phosphorus decreased at St.3. At both St.1 and St.5, the N/P ratio dropped significantly due to the decrease in nitrogen. Finally, at all stations, a significant drop in phytoplankton biomass and a significant increase in macrophyte coverage (Mann-Kendall trend test: $p<0.02$ at St.1 and $p<0.01$ at St.3 and St.5) were observed.

\subsection{Principal Component Analysis of Hydrochemical Parameters and Macrophyte Coverage}

The bi-plot of the first two PCA components highlighted the relations among environmental parameters and the similarities/dissimilarities among years or groups of years, explaining about $60 \%$ of the total variance (Figure 9). The bi-plot showed the following: (i) the oxygen, macrophyte coverage, temperature and transparency have positive loadings on Component 1 and are positively correlated with each other and negatively correlated with ammonia and chlorophyll $a$; (ii) ammonia has a negative influence on Component 1 and is positively correlated with chlorophyll $a$ and negatively so with macrophyte coverage; (iii) salinity has a negative influence on Component 2, unlike the oxidized forms of nitrogen and orthophosphates, which have a positive influence on the same component; (iv) the early years (1998-2006) form a cluster (A; Quadrants III and IV); (v) the years from 2013 to 2017, characterized by dense macrophyte coverage and high relative oxygen, temperature and transparency values, form a cluster (B; Quadrants I and II). Table 4 shows the significant differences between the averages of the hydrochemical parameters of Clusters $\mathrm{A}$ and $\mathrm{B}$. The differences are significant for transparency $(A=0.9 \mathrm{~m}$ and $\mathrm{B}=1.2 \mathrm{~m})$, relative oxygen $(\mathrm{A}=102 \%$ and $\mathrm{B}=113 \%)$, $\mathrm{N}_{-N_{3}}(\mathrm{~A}=14.70 \mu \mathrm{M}$ and $\mathrm{B}=6.01 \mu \mathrm{M}), \mathrm{N}-\mathrm{NO}_{3}(\mathrm{~A}=41.26 \mu \mathrm{M}$ and $\mathrm{B}=32.11 \mu \mathrm{M})$, chlorophyll $a$ $\left(\mathrm{A}=7.46 \mu \mathrm{g} \mathrm{L}^{-1}\right.$ and $\left.\mathrm{B}=3.26 \mu \mathrm{g} \mathrm{L}^{-1}\right)$ and macrophyte coverage $(\mathrm{A}=0 \%$ and $\mathrm{B}=44 \%)$. 


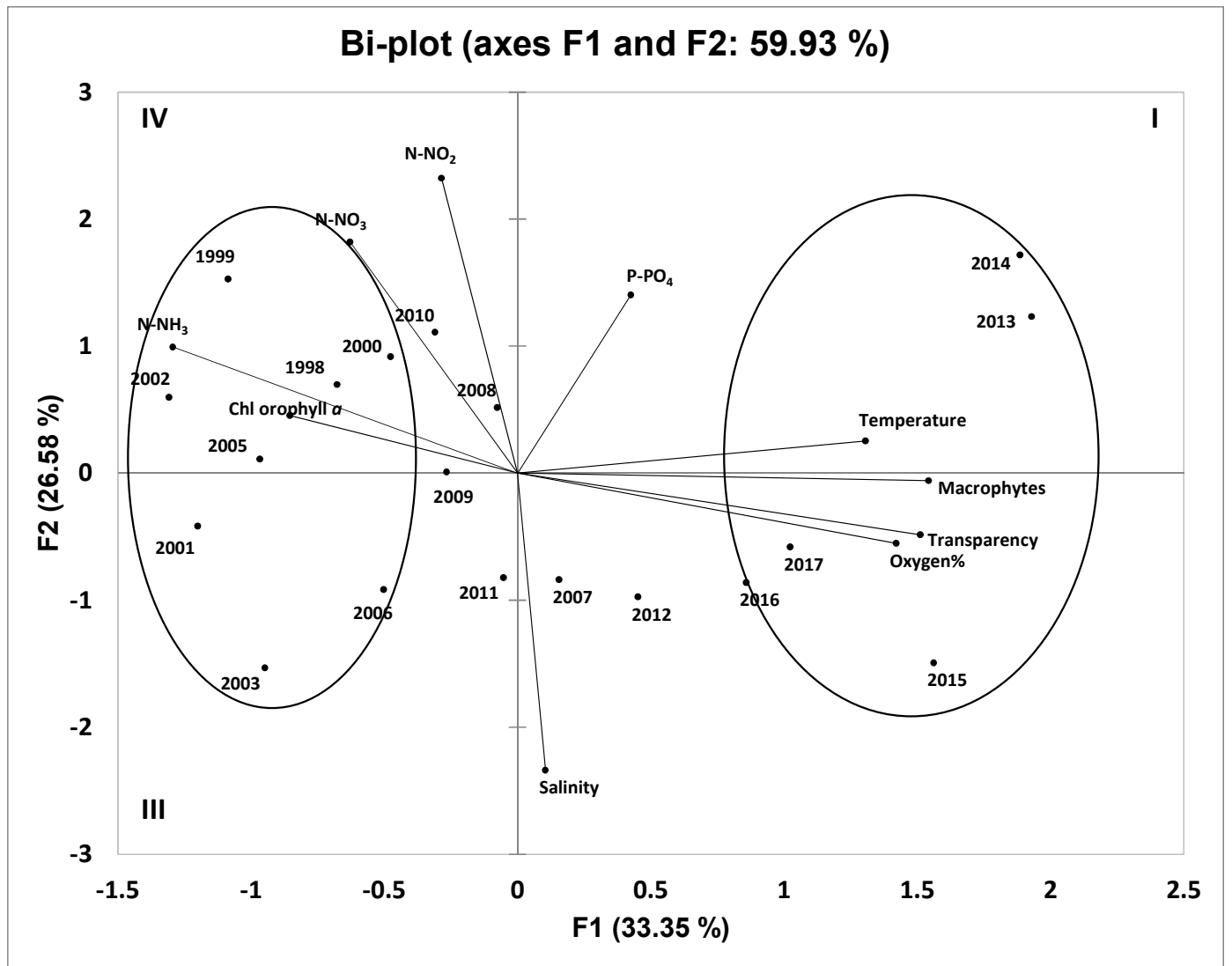

Figure 9. Principal component analysis (PCA, R-mode): the space is divided into four quadrants (I-IV) to facilitate interpretation; Cluster A = years 1998-2006; Cluster B = years 2013-2017.

Table 4. T-test of hydrochemical parameter means, highlighting differences between Cluster A and Cluster B evidenced by principal component analysis.

\begin{tabular}{|c|c|c|c|}
\hline Parameters & $\begin{array}{c}\text { Cluster A } \\
1998-2006\end{array}$ & $\begin{array}{l}\text { Cluster B } \\
2013-2017\end{array}$ & $p$ \\
\hline Transparency (m) & 0.9 & 1.2 & $<0.01$ \\
\hline Temperature $\left({ }^{\circ} \mathrm{C}\right)$ & 18.3 & 19.6 & NS \\
\hline Salinity & 26.49 & 25.96 & NS \\
\hline Relative oxygen (\%) & 102 & 113 & $<0.01$ \\
\hline $\mathrm{N}-\mathrm{NH}_{3}(\mu \mathrm{M})$ & 14.70 & 6.01 & $<0.01$ \\
\hline $\mathrm{N}-\mathrm{NO}_{2}(\mu \mathrm{M})$ & 1.75 & 1.60 & NS \\
\hline $\mathrm{N}-\mathrm{NO}_{3}(\mu \mathrm{M})$ & 41.26 & 32.11 & $<0.01$ \\
\hline $\mathrm{P}-\mathrm{PO}_{4}(\mu \mathrm{M})$ & 0.96 & 1.02 & NS \\
\hline Chlorophyll $a\left(\mu \mathrm{g} \mathrm{L}^{-1}\right)$ & 7.46 & 3.26 & $<0.01$ \\
\hline Macrophyte coverage (\%) & 0 & 44 & $<0.01$ \\
\hline
\end{tabular}

\section{Discussion}

This study involved a twenty-year hydrochemical and biological survey in three areas of the LoV, each with distinct environmental conditions due to urban, industrial and agricultural pollution and the influence of marine and fresh waters. Despite these differences, the three stations showed similar trends: rising transparency, dissolved oxygen and macrophyte coverage, as well as decreasing nitrogen nutrients (due to the application of more stringent environmental regulations) [31] and phytoplankton biomass (Table 3). This enables us to ascertain that an overall improvement in the ecological conditions of the LoV can be stated for the last years. Statistical analyses of the long-term hydrological and biological data, together with macrophyte maps derived from satellite images, made it possible to 
emphasize the succession of primary producers in the lagoon waters over the twenty years considered. However, it is difficult to identify the multiple driving factors, which overlap and counteract each other in determining interannual variations in macrophyte and phytoplankton distribution. Thus, in addition to the analysed data, other information derived from local authorities and scientific publications can contribute to explaining the different trends of macrophyte growth and development.

At the beginning of our long-term series (1998), in the sites identified for sampling, the main primary producer was phytoplankton [29,42]: the highest phytoplankton biomass was in the central basin $[29,43]$. Since 2004, only rather low levels of chlorophyll $a$ have been recorded. A peak in chlorophyll $a$ concentration was measured at the three stations in 2001. This was also observed, during the summer, in other areas of the LoV, mainly influenced by the tributaries and closer to the industrial area [65]. In these areas, the dissolved nutrient concentrations were, on average, the highest. Moreover, an enormously dense bloom of picocyanobacteria occurred in July-August of 2001 both in the LoV and along the coast of the northern Adriatic Sea [66]. These phenomena could be driven by regional factors such as the significant loads of organic suspension, nutrients and pollutants from the extreme flood of the Po River in the last months of $2000[67,68]$.

From 1998 until 2003, the three investigated areas were almost uncolonized by macrophytes. It was extensively reported that in this period, the disappearance of submerged vegetation was at least partly due to the significant illegal clam fishing [69]. This activity strongly interacted the benthic compartment and contributed to the process of sediment resuspension and erosion, causing a decrease in water transparency and light availability. In 2005, to overcome social, economic and ecological concerns related to unregulated clam fishing, local administrators allocated some areas of the lagoon to clam harvesting. As a likely consequence of clam fishing regulation, macrophytes started to recolonize the areas. In the years 2007 and 2008, all three sampling sites were characterized by an increase of $1-31 \%$ in macrophyte coverage with a density of $50-100 \%$. Water transparency gradually increased, confirming its positive feedback on the development of aquatic submerged vegetation. Additionally, favourable climatic conditions (i.e., mild air temperatures) could have influenced macrophyte growth (Figure 5). The adverse meteorological conditions in 2010-2012 probably played a very important role, with several consecutive, longer-than-usual cold seasons, which reduced the over-wintering of the macrophytes, as occurred in the 1990s [20]. Meteo-climatic analysis performed by the Veneto Regional Environmental Protection Agency (ARPAV) points out how the first months of 2010 were particularly cold and rainy compared to the average of the last 25 years, resulting in conditions less favourable for the growth and proliferation of submerged vegetation [70]. During the late winter of 2012, the northern Adriatic Sea was heavily impacted by a severe cold spell, which caused a large decrease in the surface temperature and the onset of severe north-easterly Bora winds [71]. Shallow water areas of the LoV froze, likely hampering onward macrophyte growth in April and May, as also reported by [20] in the early 1990s. Moreover, the increased coverage in 2013 was due to the exceptional rains characterizing the spring of 2013, which enriched the lagoon with dissolved nutrients from the drainage basin, through the leaching of agricultural lands subjected in spring to the usual fertilization practices, as confirmed by higher chlorophyll values in March and April. During summer, the nutrient enrichment favoured the proliferation of algae (both micro- and macro-algae) in the lagoon. The strong production of oxygen during the daytime followed by the consumption of oxygen in the night triggered anaerobic degradation processes and the production of hydrogen sulfide. The relative stagnation of the waters at the neap tide and the highest temperatures then produced hypoxia and prolonged anoxia in some areas of the lagoon. Fortunately, this was a transitory phenomenon that lasted only for a few days [72].

The results of the present study show that in recent years (2013-2017), in the three sampling sites considered, there has been an increase in dissolved oxygen together with transparency and macrophyte coverage and a concomitant decrease in nutrients and phytoplankton biomass (Table 4 and Figure 8). Our hypothesis is that in the last few years, the decrease in nutrients loads enhanced macrophyte growth at the expense of phytoplankton. Moreover, the increased area covered by macrophytes 
could explain why relative oxygenation, always measured during the daytime, increased despite the decrease in phytoplankton biomass. To confirm this, we found a positive correlation between relative oxygenation and macrophyte coverage (Figure 9). Finally, in recent years, although hypoxia/anoxia events have occurred in the sampling areas, they have been short and spatially limited, often lasting less than $24 \mathrm{~h}$ [73], while the serious and recurrent episodes of hypoxia/anoxia caused by Ulva in the 1980s have never occurred.

Since 2013, it is assumed that the decreased phytoplankton biomass and increased water transparency are enhancing macrophyte growth, and that macrophyte growth is, in turn, reducing water turbidity and phytoplankton blooms, as reported for the LoV in the past [74,75]. The sharp decrease in ammonia concentrations (Figure 2, Figure 3 andFigure 4) may also have contributed to the drop in phytoplankton biomass: according to [75], ammonia represents the main $\mathrm{N}$ source (accounting for $>70 \%$ of total $\mathrm{N}$ uptake rates) for phytoplankton nutrition. In addition, dense assemblages of macrophytes influence the nutrient cycle, because they are likely to intercept nutrients from both the water column and the sediments [76], making them less available to phytoplankton. Lastly, it is difficult to establish whether the significant decrease in the N/P ratio has favoured the proliferation of macrophytes. Indeed, there does not seem to be any direct relationship between the growth of macroalgae and the N/P ratio in the waters of the LoV [77].

Another factor that could cause macrophytes to inhibit the growth of phytoplankton is allelopathy. The allelopathic effects of macrophytes on phytoplankton are no longer questioned [78], and although it is difficult to demonstrate in situ [79] and we have no data on it, it can be assumed that the release of allelochemicals by macrophytes inhibits the growth of phytoplankton. In this regard, it has been reported that extracts from the leaves of Zostera noltii could inhibit microalgae [80]. In addition, several species of the green macroalgal genus Ulva display the ability to cause the rapid lysis of certain phytoplankton species (Prorocentrum micans, Prorocentrum donghaiense and Heterosigma akashiwo) and to reduce the growth of Alexandrium tamarense and Chaetoceros gracile [81]. Furthermore, regarding the alternating dominance of macro- or micro-producers in the LoV, [19] reported that the predominance of phytoplankton resulted from low water transparency, high grazing pressure on macroalgae and high concentrations of particulate matter on the fronds or in the water column. In addition, the interactions that determine the composition, abundance and distribution of macroalgal groups and seagrasses and their relations with their physico-chemical environment are complex and depend on sediment composition, climate, patterns of gamete dispersion, tidal currents, predation and other factors [77].

To summarize, the results of this study show that in the years 2013-2017, the overall quality of the central and northern basins of the LoV improved and these areas were recolonized by macrophytes at the expense of phytoplankton, as reported by other authors for macrophyte-dominated shallow-water systems with similar nutrient loadings [82].

To conclude, in transitional environments such as lagoons, managing macrophyte and microalgal biomass and its propagation is a key issue in order to avoid the occurrence of hypoxia/anoxia and hence the onset of critical conditions in ecosystem functioning. Mapping macrophyte coverage with a high temporal and spatial resolution, using remote sensing techniques, appears to be a useful and cost-effective method for assessing macrophyte coverage and/or for monitoring its spatial and temporal evolution. Moreover, although Landsat TM and ETM+ were designed for terrestrial applications and their applications in aquatic environments are limited, they are recognized as usable in aquatic habitat mapping $[83,84]$. The long data series from Landsat satellites provides a unique opportunity to study long-term changes in shallow-water environments. The launch of Landsat- 8 in 2013 has ensured the continuation of the data series, and the improved radiometric resolution (12-bit instead of 8-bit) is beneficial for all aquatic science applications [85-87]. However, the effectiveness of this approach requires that remote sensing by satellite is accompanied by adequate field measurements.

Future work on macrophyte seasonal patterns and coverage will provide useful information about intra-annual fluctuations of their phenology, improving the assessment of ecological status in transitional waters. Further efforts will be dedicated to distinguishing macrophyte functional 
groups, i.e., macroalgae and seagrasses, by exploiting the capability of the new hyperspectral mission, PRISMA (Italian Space Agency). The first tests are encouraging for inland and coastal applications [88]. In order to adequately understand the growth and distribution of various primary producers, the implementation of long-term series of both satellite and in situ hydro-bio-chemical data is essential, as is the contribution of taxonomists. This knowledge base could provide effective information to local authorities, reducing the costs of monitoring activities in connection with the European Water Framework Directive, and would be a useful tool for evaluating and managing future changes to the LoV ecosystem.

Supplementary Materials: The following are available online at http://www.mdpi.com/2073-4441/12/10/2810/s1. Table S1_1: Yearly averages of hydrochemical parameters in the three sampling stations for the whole study period. Lower and upper bounds of means (95\%) are shown. Table S2_1: Landsat images used for the retrieval of macrophyte coverage. Figures_S2_1: Maps of satellite-derived macrophyte coverage retrieved by BOMBER.

Author Contributions: Conceptualization, F.B.A. and F.A.; methodology, F.B.A., F.A., F.B. and G.M.S.; investigation, F.B.A., F.A., F.B. and G.M.S.; data processing, F.B.A., F.A., F.B. and G.M.S.; writing-original draft preparation, F.B.A., F.A., F.B. and G.M.S.; writing—review and editing, F.B.A., F.A., F.B. and G.M.S.; funding acquisition, F.B. All authors have read and agreed to the published version of the manuscript.

Funding: This work was also supported by the European Union's Horizon 2020-Research and Innovation Framework Programme (CoastObs project, grant number 775983). Scientific activity was partially performed in the Research Programme Venezia2021, with the contribution of the Provveditorato for the Public Works of Veneto, Trentino Alto Adige and Friuli Venezia Giulia, provided through the concessionary of State Consorzio Venezia Nuova and coordinated by CORILA.

Acknowledgments: The LoV belongs to the LTER-Italy, LTER-Europe and LTER-International Long-Term Ecological Research networks: the time series analysed in this paper was gathered in the context of these networks. The authors wish to thank F. Bianchi, E. Camatti, S. Finotto, M. Pansera and L. Dametto for their technical support during sampling and other fieldwork, and the crew of the M/B "Litus", G. Zennaro, D. Penzo and M. Penzo. Furthermore, the authors wish to thank the three anonymous referees who provided constructive comments that helped to improve the manuscript. Landsat-8 data were obtained from the U.S. Geological Survey and Earth Resources Observation and Science (EROS) Center. We thank G. Zibordi for his effort in establishing and maintaining Venise AERONET site.

Conflicts of Interest: The authors declare no conflict of interest.

\section{References}

1. Barnes, R.S.K. Coastal Lagoons, 1st ed.; Cambridge University Press: Cambridge, UK, 1980; p. 106. ISBN 780521234221.

2. Pérez-Ruzafa, A.; Marcos, C.; Perez-Ruzafa, I.M.; Pérez-Marcos, M. Coastal lagoons: "Transitional ecosystems" between transitional and coastal waters. J. Coast. Conserv. 2010, 15, 369-392. [CrossRef]

3. Newton, A.; Icely, J.; Cristina, S.C.V.; Brito, A.C.; Cardoso, A.C.; Colijn, F.; Riva, S.D.; Gertz, F.; Hansen, J.W.; Holmer, M.; et al. An overview of ecological status, vulnerability and future perspectives of European large shallow, semi-enclosed coastal systems, lagoons and transitional waters. Estuar. Coast. Shelf Sci. 2014, 140, 95-122. [CrossRef]

4. Orfanidis, S.; Panayotidis, P.; Stamatis, N. An insight to the ecological evaluation index (EEI). Ecol. Indic. 2003, 3, 27-33. [CrossRef]

5. Giordani, G.; Zaldívar, J.; Viaroli, P. Simple tools for assessing water quality and trophic status in transitional water ecosystems. Ecol. Indic. 2009, 9, 982-991. [CrossRef]

6. Sfriso, A.; Facca, C.; Bon, D.; Buosi, A. Macrophytes and ecological status assessment in the Po delta transitional systems, Adriatic Sea (Italy). Application of Macrophyte Quality Index (MaQI). Acta Adriat. 2016, 57, 209-225.

7. McGlathery, K.; Sundbäck, K.; Anderson, I. Eutrophication in shallow coastal bays and lagoons: The role of plants in the coastal filter. Mar. Ecol. Prog. Ser. 2007, 348, 1-18. [CrossRef]

8. Adriano, S.; Chiara, F.; Antonio, M. Sedimentation rates and erosion processes in the lagoon of Venice. Environ. Int. 2005, 31, 983-992. [CrossRef]

9. Duarte, C.M. Submerged aquatic vegetation in relation to different nutrient regimes. Ophelia 1995, 41, 87-112. [CrossRef] 
10. Ralph, P.J.; Durako, M.; Enríquez, S.; Collier, C.; Doblin, M. Impact of light limitation on seagrasses. J. Exp. Mar. Biol. Ecol. 2007, 350, 176-193. [CrossRef]

11. Solidoro, C.; Bandelj, V.; Bernardi, F.A.; Camatti, E.; Ciavatta, S.; Cossarini, G.; Facca, C.; Franzoi, P.; Libralato, S.; Canu, D.M.; et al. Response of Venice Lagoon Ecosystem to Natural and Anthropogenic Pressures over the Last 50 Years. In Coastal Lagoons: Critical Habitats of Environmental Change; Kennish, M.J., Paerl, H.W., Eds.; CRC Press, Taylor and Francis: Boca Raton, FL, USA, 2010; pp. 483-511.

12. Braga, F.; Scarpa, G.M.; Brando, V.E.; Manfè, G.; Zaggia, L. COVID-19 lockdown measures reveal human impact on water transparency in the Venice Lagoon. Sci. Total. Environ. 2020, 736, 139612. [CrossRef]

13. Kosten, S.; Jeppesen, E.; Huszar, V.L.M.; Mazzeo, N.; Van Nes, E.H.; Peeters, E.T.; Scheffer, M. Ambiguous climate impacts on competition between submerged macrophytes and phytoplankton in shallow lakes. Freshw. Biol. 2011, 56, 1540-1553. [CrossRef]

14. Sfriso, A.; Facca, C.; Ghetti, P. Temporal and spatial changes of macroalgae and phytoplankton in a Mediterranean coastal area: The Venice lagoon as a case study. Mar. Environ. Res. 2003, 56, 617-636. [CrossRef]

15. Sfriso, A.A.; Facca, C.; Ghetti, P.F. Validation of the Macrophyte Quality Index (MaQI) set up to assess the ecological status of Italian marine transitional environments. Hydrobiology 2008, 617, 117-141. [CrossRef]

16. Facca, C.; Aubry, F.B.; Socal, G.; Ponis, E.; Acri, F.; Bianchi, F.; Giovanardi, F.; Sfriso, A.A. Description of a Multimetric Phytoplankton Index (MPI) for the assessment of transitional waters. Mar. Pollut. Bull. 2014, 79, 145-154. [CrossRef] [PubMed]

17. Sfriso, A.; Marcomini, A.; Pavoni, B. Relationships between macroalgal biomass and nutrient concentrations in a hypertrophic area of the Venice Lagoon. Mar. Environ. Res. 1987, 22, 297-312. [CrossRef]

18. CoRiLa. Monitoraggio Matrice Praterie a Fanerogame. Available online: http://ckan.corila.it/dataset/ fanerogame (accessed on 20 July 2020).

19. Sfriso, A.; Pavoni, B. Macroalgae and phytoplankton competition in the central Venice lagoon. Environ. Technol. 1994, 15, 1-14. [CrossRef]

20. Curiel, D.; Rismondo, A.; Bellemo, G.; Marzocchi, M. Macroalgal biomass and species variations in the Lagoon of Venice (Northern Adriatic Sea, Italy): 1981-1998. Sci. Mar. 2004, 68, 57-67. [CrossRef]

21. Sfriso, A.; Marcomini, A. Decline of Ulva growth in the lagoon of Venice. Bioresour. Technol. 1996, 58, $299-307$. [CrossRef]

22. Facca, C. Trophic Conditions in the Waters of the Venice Lagoon (Northern Adriatic Sea, Italy). Open Oceanogr. J. 2011, 5, 1-13. [CrossRef]

23. Facca, C.; Ceoldo, S.; Pellegrino, N.; Sfriso, A.A. Natural Recovery and Planned Intervention in Coastal Wetlands: Venice Lagoon (Northern Adriatic Sea, Italy) as a Case Study. Sci. World J. 2014, 2014, 1-15. [CrossRef]

24. Rismondo, A.; Curiel, D.; Scarton, F.; Mion, D.; Pierini, A.; Caniglia, G. Distribution of Zostera noltii, Zostera marina and Cymodocea nodosa in Venice lagoon. In Flooding and Environmental Challenges for Venice and its Lagoon: State of Knowledge; Fletcher, C.A., Spencer, T., Eds.; Cambridge University Press: Cambridge, UK, 2005; pp. 567-572. ISBN 9780521840460.

25. Voltolina, D. The Phytoplankton of The Lagoon of Venice: November 1971-November 1972; Pubblicazioni Stazione Zoologica: Napoli, Italy, 1975; Volume 39, pp. 206-340.

26. Alberighi, L.; Bianchi, F.; Cioce, F.; Socal, G. Osservazioni durante un bloom di Skeletonema costatum in prossimità della centrale termoelettrica ENEL di Fusina Porto-Marghera (Venezia). Oebalia 1992, 17, $321-322$.

27. Socal, G.; Bianchi, F.; Alberighi, L. Effects of thermal pollution and nutrient discharges on a spring phytoplankton bloom in the industrial area of the Lagoon of Venice. Vie Milieu 1999, 49, 19-31.

28. Facca, C.; Sfriso, A.; Socal, G. Changes in Abundance and Composition of Phytoplankton and Microphytobenthos due to Increased Sediment Fluxes in the Venice Lagoon, Italy. Estuar. Coast. Shelf Sci. 2002, 54, 773-792. [CrossRef]

29. Aubry, F.B.; Acri, F.; Bianchi, F.; Pugnetti, A. Looking for patterns in the phytoplankton community of the Mediterranean microtidal Venice Lagoon: Evidence from ten years of observations. Sci. Mar. 2013, 77, 47-60. [CrossRef] 
30. Bianchi, F.; Acri, F.; Alberighi, L.; Bastianini, M.; Boldrin, A.; Cavalloni, B.; Cioce, F.; Comaschi, A.; Rabitti, S.; Socal, G.; et al. Biological variability in the Venice Lagoon. In The Venice Lagoon Ecosystem. Inputs and Interactions between Land and Sea; Lasserre, P., Marzollo, A., Eds.; UNESCO and Parthenon Publishing Press: Paris, France, 2000; pp. 97-126. ISBN 1850700834.

31. Acri, F.; Braga, F.; Aubry, F.B.B. Long-term dynamics in nutrients, chlorophyll a and water quality parameters in the Lagoon of Venice. Sci. Mar. 2020, 84. [CrossRef]

32. Sfriso, A.; Buosi, A.; Mistri, M.; Munari, C.; Franzoi, P.; Sfriso, A.A. Long-term changes of the trophic status in transitional ecosystems of the northern Adriatic Sea, key parameters and future expectations: The lagoon of Venice as a study case. Nat. Conserv. 2019, 34, 193-215. [CrossRef]

33. Malthus, T.J. Bio-optical Modeling and Remote Sensing of Aquatic Macrophytes. In Bio-optical Modeling and Remote Sensing of Inland Waters; Mishra, D.R., Ogashawara, I., Gitelson, A., Eds.; Elsevier: Amsterdam, The Netherlands, 2017; pp. 263-308.

34. Hedley, J.D.; Roelfsema, C.; Brando, V.E.; Giardino, C.; Kutser, T.; Phinn, S.; Mumby, P.J.; Barrilero, O.; Laporte, J.; Koetz, B. Coral reef applications of Sentinel-2: Coverage, characteristics, bathymetry and benthic mapping with comparison to Landsat 8. Remote Sens. Environ. 2018, 216, 598-614. [CrossRef]

35. Kutser, T.; Hedley, J.; Giardino, C.; Roelfsema, C.; Brando, V.E. Remote sensing of shallow waters-A 50 year retrospective and future directions. Remote Sens. Environ. 2020, 240, 111619. [CrossRef]

36. Ackleson, S.; Klemas, V. Remote sensing of submerged aquatic vegetation in lower chesapeake bay: A comparison of Landsat MSS to TM imagery. Remote Sens. Environ. 1987, 22, 235-248. [CrossRef]

37. Dekker, A.G.; Brando, V.E.; Anstee, J.M. Retrospective seagrass change detection in a shallow coastal tidal Australian lake. Remote Sens. Environ. 2005, 97, 415-433. [CrossRef]

38. Knudby, A.; Newman, C.; Shaghude, Y.; Muhando, C. Simple and effective monitoring of historic changes in nearshore environments using the free archive of Landsat imagery. Int. J. Appl. Earth Obs. Geoinf. 2010, 12, S116-S122. [CrossRef]

39. Poggioli, S. MOSE Project Aims to Part Venice Floods. Available online: https://www.npr.org/templates/ story/story.php?storyId=17855145\&t=1595252078841 (accessed on 20 July 2020).

40. Bianchi, F.; Acri, F.; Aubry, F.; Berton, A.; Boldrin, A.; Camatti, E.; Cassin, D.; Comaschi, A. Can plankton communities be considered as bio-indicators of water quality in the Lagoon of Venice? Mar. Pollut. Bull. 2003, 46, 964-971. [CrossRef]

41. Scarpa, G.M.; Zaggia, L.; Manfè, G.; Lorenzetti, G.; Parnell, K.; Soomere, T.; Rapaglia, J.; Molinaroli, E. The effects of ship wakes in the Venice Lagoon and implications for the sustainability of shipping in coastal waters. Sci. Rep. 2019, 9, 1-14. [CrossRef] [PubMed]

42. Adriano, S.; Chiara, F.; Sonia, C.; Antonio, M. Recording the occurrence of trophic level changes in the lagoon of Venice over the '90s. Environ. Int. 2005, 31, 993-1001. [CrossRef]

43. Sfriso, A.A.; Facca, C. Distribution and production of macrophytes and phytoplankton in the lagoon of Venice: Comparison of actual and past situation. Hydrobiology 2007, 577, 71-85. [CrossRef]

44. WEPAL. QUASIMEME Laboratory Performance Studies. Available online: http://www.quasimeme.org (accessed on 28 July 2020).

45. Zipper, C.E.; Holtzman, G.I.; Darken, P.F.; Stewart, R.E.; Thomas, P.J.; Gildea, J.J. Surface-Water Quality Trend Analysis: A Multiple-Site Application. In Advances in Water Monitoring Research; Younos, T., Ed.; Water Resources Publications, LLC: Littleton, CO, USA, 2002; pp. 77-103. ISBN 1887201335.

46. Sen, P.K. Estimates of the Regression Coefficient Based on Kendall's Tau. J. Am. Stat. Assoc. 1968, 63, 1379-1389. [CrossRef]

47. Drápela, K.; Drápelová, I. Application of Mann-Kendall test and the Sen's slope estimates for trend detection in deposition data from Bílý Kř́ž (Beskydy Mts., the Czech Republic) 1997-2010. Beskydy 2011, 4, 133-146.

48. Curiel, D.; Falace, A.; Bandelj, V.; Rismondo, A. Applicability and intercalibration of macrophyte quality indices to characterise the ecological status of Mediterranean transitional waters: The case of the Venice lagoon. Mar. Ecol. 2012, 33, 437-459. [CrossRef]

49. Sfriso, A.; Facca, C.; Ceoldo, S. Growth and production of Cymodocea nodosa (Ucria) Ascherson in the Venice lagoon. In Scientific Research and Safeguarding of Venice. CoRiLa. Research Programme 2001-2003. 2002 Results; Campostrini, P., Ed.; Multigraf Spinea: Venezia, Italy, 2004; pp. 229-236. ISBN 9788889405000. 
50. Phinn, S.R.; Roelfsema, C.; Dekker, A.; Brando, V.; Anstee, J. Mapping seagrass species, cover and biomass in shallow waters: An assessment of satellite multi-spectral and airborne hyper-spectral imaging systems in Moreton Bay (Australia). Remote Sens. Environ. 2008, 112, 3413-3425. [CrossRef]

51. Giardino, C.; Bresciani, M.; Cazzaniga, I.; Schenk, K.; Rieger, P.; Braga, F.; Matta, E.; Brando, V.E. Evaluation of Multi-Resolution Satellite Sensors for Assessing Water Quality and Bottom Depth of Lake Garda. Sensors 2014, 14, 24116-24131. [CrossRef]

52. Ghirardi, N.; Bolpagni, R.; Bresciani, M.; Valerio, G.; Pilotti, M.; Giardino, C. Spatiotemporal Dynamics of Submerged Aquatic Vegetation in a Deep Lake from Sentinel-2 Data. Water 2019, 11, 563. [CrossRef]

53. Villa, P.; Bresciani, M.; Bolpagni, R.; Braga, F.; Bellingeri, D.; Giardino, C. Impact of upstream landslide on perialpine lake ecosystem: An assessment using multi-temporal satellite data. Sci. Total Environ. 2020, 720, 137627. [CrossRef] [PubMed]

54. Vermote, E.F.; Tanré, D.; Deuzé, J.L.; Herman, M.; Morcrette, J.J.; Kotchenova, S.Y. Second Simulation of a Satellite Signal in the Solar Spectrum-Vector (6SV). Available online: http://6s.ltdri.org/pages/manual.html (accessed on 28 July 2020).

55. Smirnov, A.; Holben, B.N.; Eck, T.F.; Slutsker, I.; Chatenet, B.; Pinker, R.T. Diurnal variability of aerosol optical depth observed at AERONET (Aerosol Robotic Network) sites. Geophys. Res. Lett. 2002, 29, 30-31. [CrossRef]

56. Mobley, C.D. Estimation of the remote-sensing reflectance from above-surface measurements. Appl. Opt. 1999, 38, 7442-7455. [CrossRef]

57. Giardino, C.; Candiani, G.; Bresciani, M.; Lee, Z.; Gagliano, S.; Pepe, M. BOMBER: A tool for estimating water quality and bottom properties from remote sensing images. Comput. Geosci. 2012, 45, 313-318. [CrossRef]

58. Santini, F.; Alberotanza, L.; Cavalli, R.M.; Pignatti, S. A two-step optimization procedure for assessing water constituent concentrations by hyperspectral remote sensing techniques: An application to the highly turbid Venice lagoon waters. Remote Sens. Environ. 2010, 114, 887-898. [CrossRef]

59. Braga, F.; Giardino, C.; Bassani, C.; Matta, E.; Candiani, G.; Strömbeck, N.; Adamo, M.; Bresciani, M. Assessing water quality in the northern Adriatic Sea from HICO ${ }^{\text {тм }}$ data. Remote Sens. Lett. 2013, 4, 1028-1037. [CrossRef]

60. Atlante della laguna. Fanerogame: Rilievo del 2009. Distribuzione delle specie Zostera marina, Zostera noltii, e Cymodocea nodosa. Available online: http://cigno.atlantedellalaguna.it/layers/geonode\%3Arilievi_ fanerogame_2009 (accessed on 25 September 2020).

61. SOLVe. Mappatura delle fanerogame marine presenti in laguna di Venezia 2017. Available online: http://solve.corila.it/maps/311\#/ (accessed on 25 September 2020).

62. ARPAV. Rete stato ambientale. La tipizzazione: Il percorso per definire rete e monitoraggio. Available online: https:/www.arpa.veneto.it/temi-ambientali/acqua/acque-di-transizione/laguna-di-venezia/ la-rete-di-monitoraggio/rete-stato-ambientale (accessed on 28 July 2020).

63. ARPAV. A proposito di cambiamenti climatici. Available online: file://C:/Users/user/Downloads/A_ proposito_di_Cambiamenti_climatici_2017.pdf (accessed on 25 September 2020).

64. Cucco, A.; Umgiesser, G. Modeling the Venice Lagoon residence time. Ecol. Model. 2006, 193, 34-51. [CrossRef]

65. Solidoro, C.; Pastres, R.; Cossarini, G.; Ciavatta, S. Seasonal and spatial variability of water quality parameters in the lagoon of Venice. J. Mar. Syst. 2004, 51, 7-18. [CrossRef]

66. Sorokin, P.; Sorokin, Y.; Boscolo, R.; Giovanardi, O. Bloom of Picocyanobacteria in the Venice Lagoon During Summer-Autumn 2001: Ecological Sequences. Hydrobiology 2004, 523, 71-85. [CrossRef]

67. Boldrin, A.; Langone, L.; Miserocchi, S.; Turchetto, M.; Acri, F. Po River plume on the Adriatic continental shelf: Dispersion and sedimentation of dissolved and suspended matter during different river discharge rates. Mar. Geol. 2005, 222, 135-158. [CrossRef]

68. Aubry, F.B.; Acri, F.; Bastianini, M.; Bianchi, F.; Cassin, D.; Pugnetti, A.; Socal, G. Seasonal and interannual variations of phytoplankton in the Gulf of Venice (Northern Adriatic Sea). Chem. Ecol. 2006, 22, S71-S91. [CrossRef] 
69. Raicevich, S.; Granzotto, A.; Pastres, R.; Giovanardi, O.; Fabio, P.; Libralato, S. Mechanical clam dredging in Venice lagoon: Ecosystem effects evaluated with a trophic mass-balance model. Mar. Biol. 2003, 143, $393-403$. [CrossRef]

70. ARPAV. Analisi meteoclimatica dell'Inverno 2009/2010. Available online: https://www.arpa.veneto.it/temiambientali/climatologia/dati/analisi-meteoclimatica-dellinverno-2009-2010 (accessed on 10 September 2020).

71. Aubry, F.B.; Falcieri, F.M.; Chiggiato, J.; Boldrin, A.; Luna, G.M.; Finotto, S.; Camatti, E.; Acri, F.; Sclavo, M.; Carniel, S.; et al. Massive shelf dense water flow influences plankton community structure and particle transport over long distance. Sci. Rep. 2018, 8, 4554. [CrossRef] [PubMed]

72. Bastianini, M.; Bernardi Aubry, F.; Acri, F.; Braga, F.; Facca, C.; Sfriso, A.; Finotto, S. The Redentore fish die-off in the Lagoon of Venice: An integrated view. In Società Botanica Italiana, Gruppo di Ia riunione scientifica annuale. Tumori J. 1974, 60, 439. [CrossRef]

73. ARPAV. Risultati monitoraggio ecologico 2014 2016-Laguna di Venezia.pdf. Available online: https://www.arpa.veneto.it/temi-ambientali/acqua/file-e-allegati/documenti/acque-di-transizione/ rapporti-finali-e-documenti-di-classificazione-laguna-di-venezia/Risultati\%20monitoraggio\% 20ecologico\%202014\%202016\%20-\%20Laguna\%20di\%20Venezia.pdf/at_download/file (accessed on 28 July 2020).

74. Sfriso, A.; Pavoni, B.; Marcomini, A.; Orio, A.A. Macroalgal production and nutrient recycling in the lagoon of Venice. Ing. Sanitaria 1988, 5, 255-266.

75. Pascal, M.; Lasserre, P.; Madec, C.; Le Corre, P.; Macé, E.; Cavalloni, B. Pelagic Nitrogen Fluxes in the Venice Lagoon. In The Venice Lagoon Ecosystem. Inputs and Interactions between Land and Sea; Lasserre, P., Marzollo, A., Eds.; UNESCO and Parthenon Publishing Press: Paris, France, 2000; pp. 143-186. ISBN 1850700834.

76. Tyler, A.C.; McGlathery, K.J.; Anderson, I.C. Benthic algae control sediment-water column fluxes of organic and inorganic nitrogen compounds in a temperate lagoon. Limnol. Oceanogr. 2003, 48, 2125-2137. [CrossRef]

77. Zirino, A.; Elwany, H.; Facca, C.; Maicu', F.; Neira, C.; Mendoza, G. Nitrogen to phosphorus ratio in the Venice (Italy) Lagoon (2001-2010) and its relation to macroalgae. Mar. Chem. 2016, 180, 33-41. [CrossRef]

78. Hilt, S. Regime shifts between macrophytes and phytoplankton-Concepts beyond shallow lakes, unravelling stabilizing mechanisms and practical consequences. Limnetica 2015, 32, 467-480. [CrossRef]

79. Vanderstukken, M.; Mazzeo, N.; Van Colen, W.; Declerck, S.A.J.; Muylaert, K. Biological control of phytoplankton by the subtropical submerged macrophytes Egeria densa and Potamogeton illinoensis: A mesocosm study. Freshw. Biol. 2011, 56, 1837-1849. [CrossRef]

80. Laabir, M.; Grignon-Dubois, M.; Masseret, E.; Rezzonico, B.; Soteras, G.; Rouquette, M.; Rieuvilleneuve, F.; Cecchi, P. Algicidal effects of Zostera marina L. and Zostera noltii Hornem. extracts on the neuro-toxic bloom-forming dinoflagellate Alexandrium catenella. Aquat. Bot. 2013, 111, 16-25. [CrossRef]

81. Tang, Y.Z.; Gobler, C.J. The green macroalga, Ulva lactuca, inhibits the growth of seven common harmful algal bloom species via allelopathy. Harmful Algae 2011, 10, 480-488. [CrossRef]

82. Grall, J.; Chauvaud, L. Marine eutrophication and benthos: The need for new approaches and concepts. Glob. Chang. Biol. 2002, 8, 813-830. [CrossRef]

83. Zhang, X. On the estimation of biomass of submerged vegetation using Landsat thematic mapper (TM) imagery: A case study of the Honghu Lake, PR China. Int. J. Remote Sens. 1998, 19, 11-20. [CrossRef]

84. El-Askary, H.; El-Mawla, S.H.A.; Li, J.; El-Hattab, M.M.; El-Raey, M. Change detection of coral reef habitat using Landsat-5 TM, Landsat 7 ETM+ and Landsat 8 OLI data in the Red Sea (Hurghada, Egypt). Int. J. Remote Sens. 2014, 35, 2327-2346. [CrossRef]

85. Irons, J.R.; Dwyer, J.L.; Barsi, J.A. The next Landsat satellite: The Landsat Data Continuity Mission. Remote Sens. Environ. 2012, 122, 11-21. [CrossRef]

86. Roelfsema, C.M.; Kovacs, E.M.; Ortiz, J.C.; Wolff, N.H.; Callaghan, D.P.; Wettle, M.; Ronan, M.; Hamylton, S.M.; Mumby, P.J.; Phinn, S.R. Coral reef habitat mapping: A combination of object-based image analysis and ecological modelling. Remote Sens. Environ. 2018, 208, 27-41. [CrossRef] 
87. Kovács, E.; Roelfsema, C.M.; Lyons, M.B.; Zhao, S.; Phinn, S.R. Seagrass habitat mapping: How do Landsat 8 OLI, Sentinel-2, ZY-3A, and Worldview-3 perform? Remote Sens. Lett. 2018, 9, 686-695. [CrossRef]

88. Giardino, C.; Bresciani, M.; Braga, F.; Fabbretto, A.; Ghirardi, N.; Pepe, M.; Gianinetto, M.; Colombo, R.; Cogliati, S.; Ghebrehiwot, S.; et al. First Evaluation of PRISMA Level 1 Data for Water Applications. Sensors 2020, 20, 4553. [CrossRef]

(C) 2020 by the authors. Licensee MDPI, Basel, Switzerland. This article is an open access article distributed under the terms and conditions of the Creative Commons Attribution (CC BY) license (http://creativecommons.org/licenses/by/4.0/). 